\title{
6
}

\section{The Batanes Pottery Sequence, 2500 BC to Recent}

\author{
Peter Bellwood, Eusebio Dizon and Alexandra De Leon
}

This chapter describes the sequential changes that occurred in pottery shape and decoration during the 4000 years of recorded Batanes prehistory. The major assemblages discussed come from Torongan Cave, Reranum rockshelter and Anaro on Itbayat, Mitangeb on Siayan Island, Sunget on Batan, and Savidug Dune Site on Sabtang.

The sequence of change in pottery form and decoration presented here for Batanes, covering almost 4000 years, is only matched within the Philippines by the related sequence from the Cagayan Valley in northern Luzon, most recently analysed by Ogawa (2000, 2002), Mijares (2006) and Hung (2008; Hung et al. 2011; Carson et al. 2013). Greater understanding of Philippine prehistory from the Neolithic onwards will require a much stronger chronological framework for ceramic change than exists at present, extending through long periods of time and covering different regions of the archipelago. The famous Tabon Cave sequence described by Fox (1970) made a start in this regard, but was mainly concerned with surface decoration, in many cases of sherds from undated and disturbed jar burials in caves. The Fuga Moro Island (northeastern Luzon) study of Snow and Shutler (1985) was concerned only with sherds from very late prehistory, and thereby lacked significant time depth. The recent thesis on Batanes pottery by Alexandra de Leon (2008) is an important development in this regard, and some of her analyses of the pottery from Savidug and Anaro are incorporated in this chapter.

The Batanes landscape is liberally littered with sherds of pottery. In the central and northern parts of Batan Island, any surface sherds collected from locations buried by the AD 500 Iraya eruption can be virtually guaranteed to be less than 1500 years old, except where the ground has been disturbed by road cuttings, latrine pits and the like. In other areas unaffected by the eruption, much older pottery can sometimes be found in surface exposures, as for instance in vast quantities from $1200 \mathrm{BC}$ onwards around the slopes of the Anaro hilltop site on Itbayat. But excavations of both deep stratigraphic profiles and well-integrated single-period assemblages, together with radiocarbon dating, are needed in order to place the different types of pottery in a time sequence. In this chapter, the pottery from Batanes is described in approximate chronological order from the excavated assemblages, beginning with assemblages from Itbayat, then Batan and Sabtang, before summarising the sequence as a whole. The burial jars from Savidug have already been described in chapter 4 . 


\section{Torongan Cave, Itbayat (c.2000 to $1200 \mathrm{BC})$}

The Torongan pottery comes essentially from two contexts, the first being the well stratified and dated layer of in-washed topsoil concentrated between 40 and $65 \mathrm{~cm}$ depth in squares A-D, the other being the up-slope and shallow square X plus the scattered surface finds (Fig. 2.5). Only the former in-washed topsoil context can be considered reliably dated, but unfortunately the sherds from here are small and eroded.

Most of the roughly 3000 sherds recovered from Torongan cave are either plain or red-slipped. Unlike Reranum (below), no cord-marked sherds were recovered. Torongan does have three circlestamped sherds with white lime or clay infilling, but these occur in the upper part of the excavated stratigraphy and appear to be relatively late in the sequence (Table 2.1; Fig. 6.1, top left).

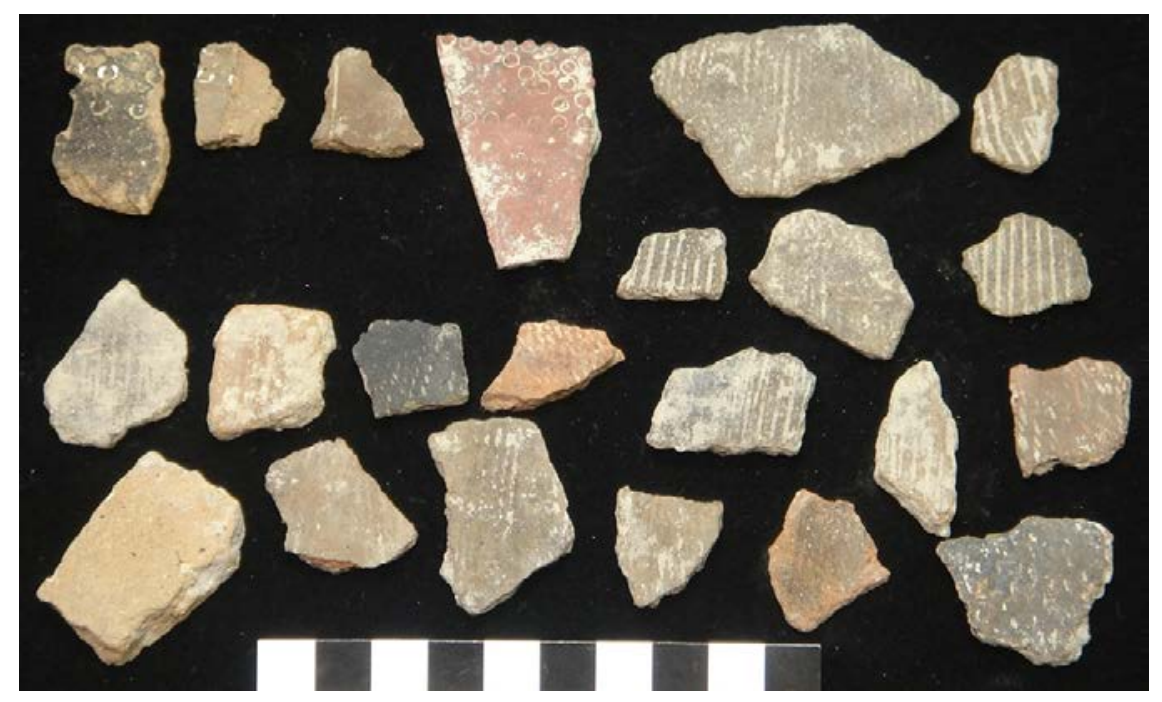

Figure 6.1. Top left: Torongan: two circle-stamped and one incised sherd with white infill, identified in the latter sherd as white clay (not lime) by Alan Watchman. Remainder of photo: Reranum: red-slipped and white in-filled circle-stamped sherd (top centre) and 18 small cord-marked sherds.

Source: Peter Bellwood.

All the rim sherds from the in-washed topsoil that can be reconstructed below the neck come from pots with everted rims, $18-20 \mathrm{~cm}$ in diameter, with the rims having mostly unthickened profiles and rounded lips (Fig. 6.2, top). There is one foot ring fragment too small to draw. Three rim sherds from one vessel shown in Fig. 6.2 (square B $45-50 \mathrm{~cm}$, 4th from top on left) have an outer thickening of the lip, paralleled in the Taiwan Middle Neolithic at sites such as Suogang, Nangang (both in the Penghu Islands), Niupu, Dazhuwei, Wanlijiatou and Fengbitou (Hung 2008:126). One rim shown in Fig. 6.2 (top right) has a flat lip, and some others have sharp internal neck angles similar to some rims excavated by Hung (2008) from Chaolaiqiao (2200 BC) in southeastern Taiwan (Fig. 6.2, middle). Some Torongan rims reveal faint traces of red slip, but insufficient survives for any precise statement to be made about the frequency of this surface finish.

Overall, the Torongan rim profiles match well with contemporary pottery $(c .2000 \mathrm{BC})$ in Taiwan, including that from Chaolaiqiao and Donghebei near Taidong on the southeastern coast (Fig. 6.2, lower). Furthermore, like Torongan, Chaolaiqiao also has almost no cord-marked sherds, but it is precisely dated by two excellent AMS C14 samples to 2200 cal. BC (Hung 2008: chapter 5). Torongan and Chaolaiqiao thus have a strong chronological tie in this regard. 


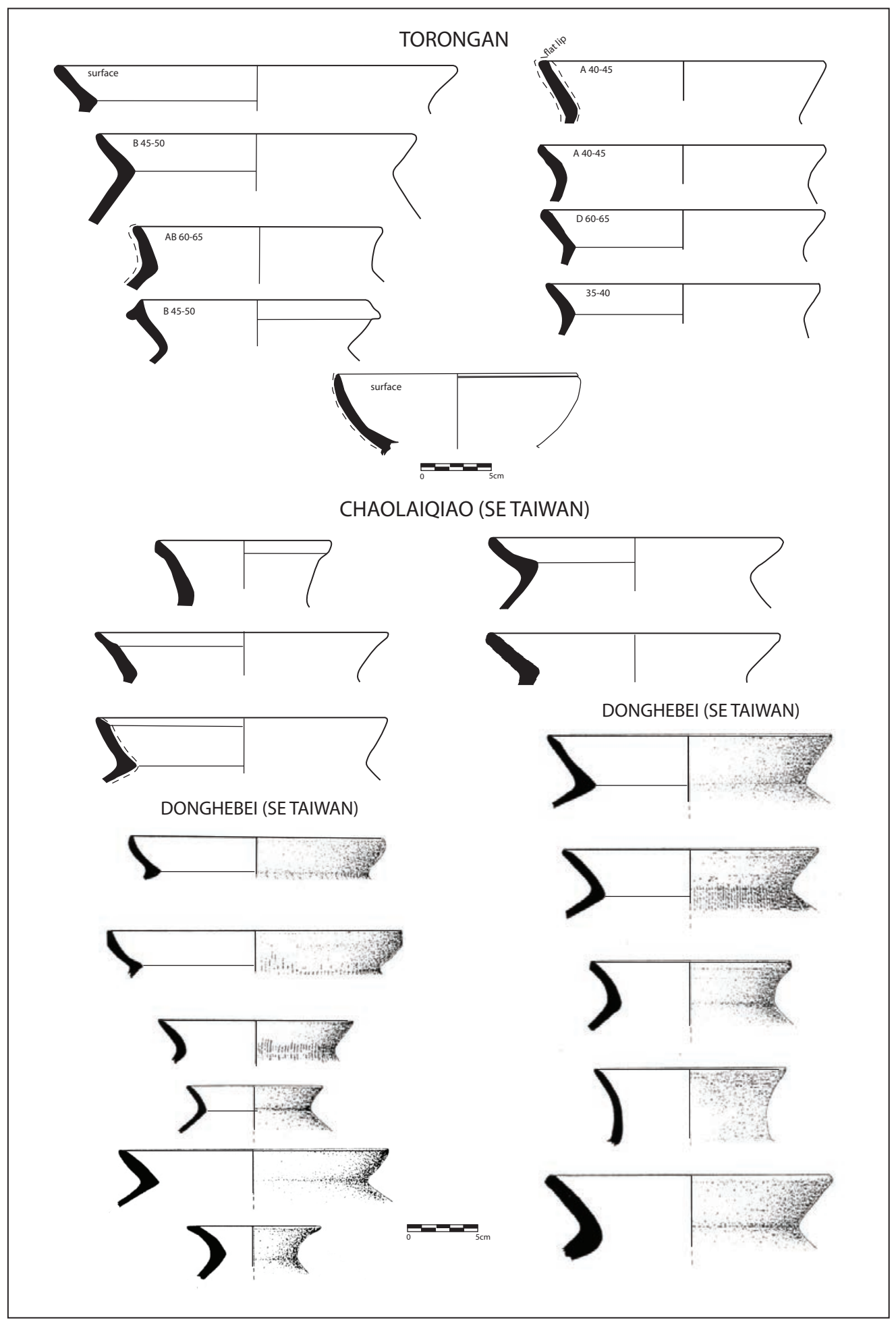

Figure 6.2. Top: rim forms from Torongan Cave. Dotted lines indicate visible traces of surface resin or red slip. Middle: comparable jar rims from Chaolaiqiao, southeastern Taiwan, 2000-2200 BC. Bottom: comparable jar rims from the site of Donghebei in southeastern Taiwan, after Chu (1990). Many of the Donghebei vessels are cord-marked, unlike those from Torongan and Chaolaiqiao. 


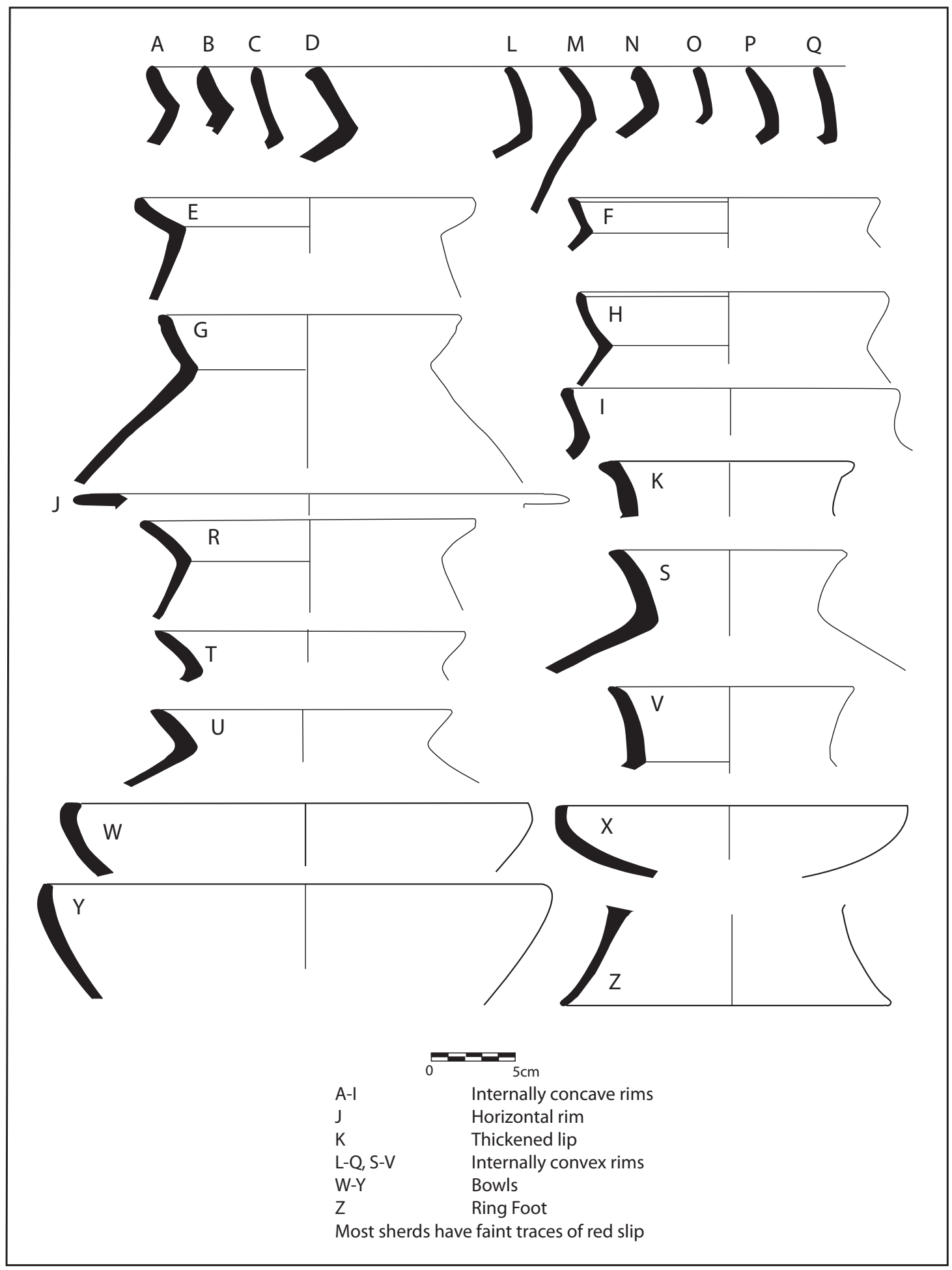

Figure 6.3. Jar rims from Reranum shelter. The top line contains sherds too small for diameter calculation. These sherds are from both excavated and surface contexts.

Source: Peter Bellwood.

The unstratified sherds from Torongan, including those from square $\mathrm{X}$, also contain a few ring feet and a handle attachment, the latter possibly for some kind of loop handle. The surface finds 
also include sherds of open bowls with direct rims on ring feet (Fig. 6.2, above upper scale), although no certain sherds of open bowls occurred in the in-washed topsoil. To avoid confusion, it is best if these sherds are considered undated in the present state of knowledge about Torongan.

The total collection of everted rims from Torongan contains 53 measureable examples, of which $36(68 \%)$ are over $30 \mathrm{~mm}$ tall above the neck externally, with a maximum height of $39 \mathrm{~mm}$. Torongan absolute neck heights are noticeably shorter on average than those from Reranum. This "rim height metric" or "tallness value" is discussed further below.

\section{Reranum shelter (second millennium BC)}

Almost 2700 sherds were unearthed from the 3 square metres, maximum depth $50 \mathrm{~cm}$, excavated in 2006 in Reranum shelter (not including the sample of large sherds thrown out of the shelter in the recent past) (Table 2.2). As at Torongan, most are plain, with sand tempers. Only 20 are decorated $(0.007 \%)$, all cord-marked except for a single circle-stamped sherd from $15-20 \mathrm{~cm}$ (Fig. 6.1). Also like Torongan, many sherds have traces of red slip, again too fugitive to present useful statistics. Besides the rim and body sherds there are also parts of body carinations and ring feet, but no handles.

The cord-marked sherds are very small compared to most of the other sherds from the site, suggesting that perhaps they were derived from an older and more trampled deposit that no longer survives with any stratigraphic clarity. If this is so, then the majority of the Reranum plain rims could be younger than the cord-marked sherds, although younger by how much cannot be known. The only relevant radiocarbon date from the site, on a marine shell from $25-30 \mathrm{~cm}$ in square A (Table 5.1, Fig. 5.1), falls in the late second millennium BC. The cord-marked pottery would appear to be older than this, given its absence from any other sites in the northern Philippines (except for one surface sherd from Anaro, below) and its apparent disappearance in southeastern Taiwan by about 2000/1500 BC, as discussed by Hung $(2005,2008)$.

Regarding the Reranum vessel forms, a number of rim sherds, particularly from the surface finds outside the shelter, are sufficiently large to allow reconstruction of the upper shapes of the vessels (Fig. 6.3). As at Torongan, most are everted jar rims, with a few open and direct bowl rims. Reranum also has a fragment of a horizontally everted rim (Fig. 6.3J) of a type reported from a number of Middle Neolithic sites in Taiwan (Hung 2008: Fig. 3.7). These similarities mean that the Reranum assemblage fits well into a date range of 2000 to $1500 \mathrm{BC}$ on Taiwan parallels. However, the Reranum rims are on average taller than those from Torongan, with 26 out of a total of 35 measurable examples (74\%) being over $30 \mathrm{~mm}$ high, and with maximum external heights up to $63 \mathrm{~mm}$ as opposed to the $39 \mathrm{~mm}$ maximum at Torongan. Reranum also has 4 foot rings with complete profiles, with the highest being $72 \mathrm{~mm}$ (Fig. 6.3Z). The tallness of the rims suggests that the Reranum assemblage, minus the cord-marked sherds, could be slightly younger than that from Torongan (see below).

\section{Comparative observations on the Torongan and Reranum pottery}

The dominant unthickened and relatively tall everted rims with rounded lips from Torongan and Reranum are similar to the majority of rim forms from Middle Neolithic sites such as Donghebei and Chaolaiqiao (Fig. 6.2) in southeastern Taiwan, the latter dating to 2200 BC. In the case of Chaolaiqiao there is a predominance of red slip, with almost no cord-marking. Hsiao-chun Hung $(2005,2008)$ has compared the Reranum rims with these two Taiwan sites and notes strong similarities in the presences of fairly tall rims with unthickened concave or convex internal profiles. She also notes the presence in all these sites of a sharp angle on the insides of some lips. 
Indeed, simple comparison of Figs 6.2 and 6.3 demonstrates how generically similar are the rims from Reranum, Torongan, Chaolaiqiao and Donghebei in terms of cross-section, rarity of thickening, and angle of eversion.

At present, there seem to be two possible differences between the Reranum and Torongan assemblages in terms of rim characteristics. The restricted vessels at Reranum have orifice diameters of two sizes, the majority between 18 and $20 \mathrm{~cm}$ as at Torongan, but there are also a few with diameters of only about $12 \mathrm{~cm}$ (Fig. 6.3, K, S and V). Torongan appears to lack the smaller diameter rims, that could have served as containers for liquids, but this could just reflect small sample size. Secondly, Reranum has taller rims on average than Torongan, and in this regard is more closely related to the assemblage of Sunget on Batan Island, which dates to $c .1000$ BC. However, Reranum, unlike Sunget and Anaro, lacks circle stamping (except for one sherd), and so seems to be older than either of these $c .1200 \mathrm{BC}$ and onwards assemblages.

The Torongan and Reranum pottery assemblages therefore establish a baseline for Batanes pottery evolution through prehistory, commencing at around 2000 BC with simple jar and bowl forms with red-slipped and plain surfaces, extremely rare cord-marking, and occasional foot rings and body carinations.

\section{The Anaro and Mitangeb (Siayan Island) pottery sequences (c.1500 BC to recent)}

Because Anaro and Mitangeb contain a number of separate excavation sequences, this section will consider first the pottery sequence excavated at Anaro 3, followed by Anaro 2 and Anaro 6, and then the site of Mitangeb on Siayan Island. The other squares excavated at Anaro were all too shallow to merit separate discussion. Then will follow a discussion of Anaro pottery surface finds, especially of stylistic elements such as lugs and figurines that are rare in the excavated collections. There is also a surface collection of "early" tall rim sherds from Anaro 5 that resemble the rims from Reranum and Sunget on Batan. Two major elements of pottery typology will be emphasised as they changed through time - rim profiles, and surface decoration - the latter mainly in the form of stamped circle motifs.

The distributions of pottery materials for Anaro 3, 2 and 6 respectively, by $10 \mathrm{~cm}$ spit (the site was dug in $5 \mathrm{~cm}$ spits, but $10 \mathrm{~cm}$ spits are sufficient for analytical purposes), are shown in Tables 6.1, 6.2, 6.4 and 6.5, together with the stratigraphic positions of radiocarbon dates. Most of the analytical detail comes from the squares Anaro 3 (dug in 2004) and Anaro 3A, 3B and 3C (dug in 2005). The pottery from 3B is dealt with by Sandy De Leon in more detail below. The diagnostic material from Anaro 3D, 3E and 3G (dug in 2006) was left in Manila and the body sherds from these squares were left on site. However, some information from notes on these squares is incorporated into the analysis.

Anaro 3 rim sherds are shown in Fig. 6.4, top left and top right, the former from above $40 \mathrm{~cm}$, the latter from below $40 \mathrm{~cm}$ down to bedrock. As far as vessel body shapes are concerned, it is assumed that those with everted rims served as cooking pots, storage jars or vessels for storing liquids, and that those with direct rims (open bowls, presumably often on foot rings) functioned for food serving. 


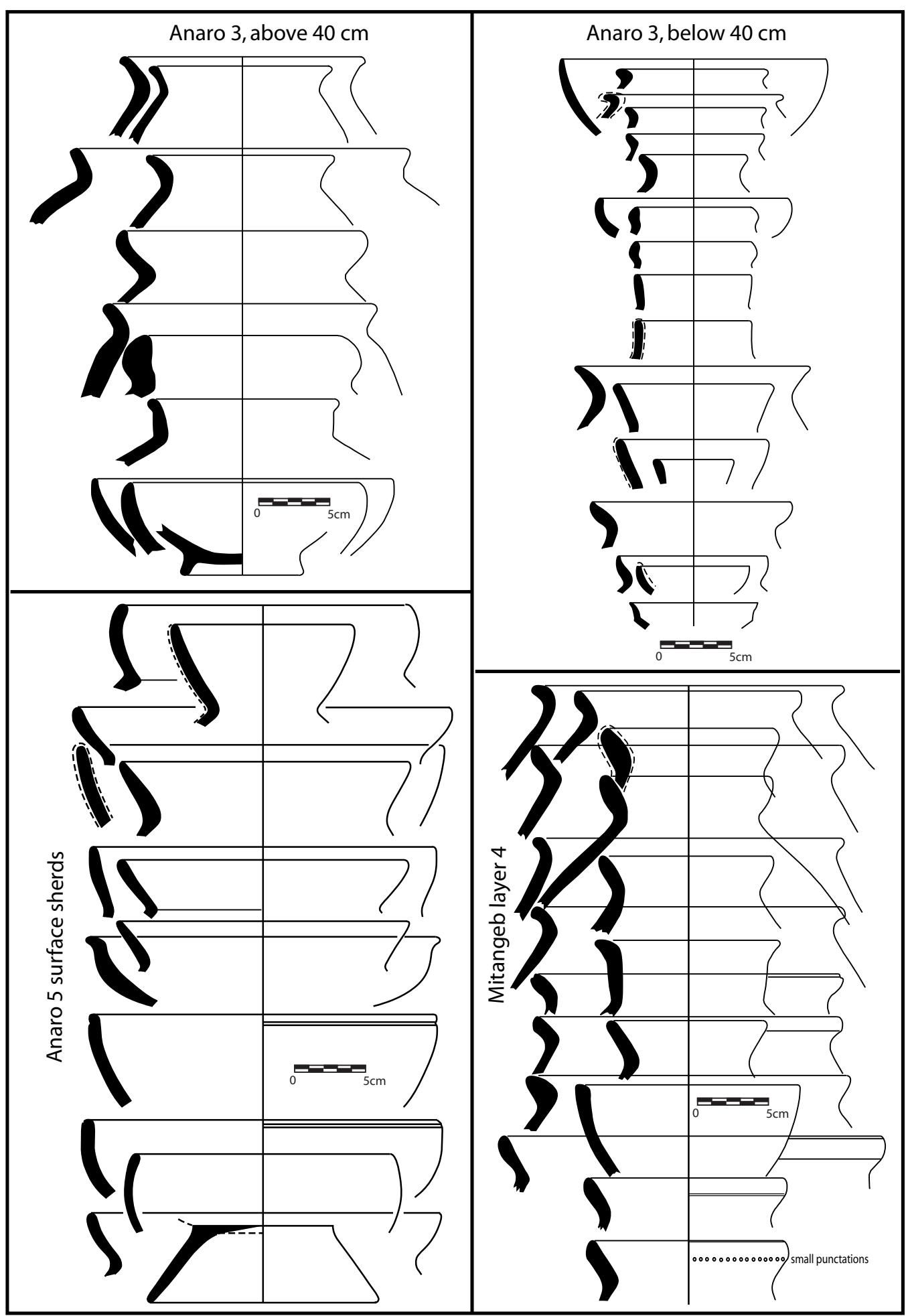

Figure 6.4. Undecorated rims from Anaro and Mitangeb. Top left: Anaro 3, above $40 \mathrm{~cm}$. Top right: Anaro 3, below $40 \mathrm{~cm}$. Bottom left: surface rims of Reranum affinity, including tall everted types, from Anaro 5. Bottom right: non-corrugated rims from Mitangeb layer 4. Dotted lines indicate red slip. 
As at Mitangeb (below), there seem to be two modal diameters for the vessels with everted rims, one around 10-12 cm, perhaps for liquids, the other larger at 16-20 cm, perhaps for cooking or solid storage. These can be differentiated very clearly in the drawings of the sherds below $40 \mathrm{~cm}$ from Anaro, as well as the sherds from Mitangeb portrayed just below in the same figure.

Tables 6.1 and 6.2 reveal a number of changes in the Anaro 3 squares through time. Only the lower layers have circle-stamped pottery. The sherds are generally bigger in the upper layers, the older sherds tend to be slightly thinner than the upper ones, and the older rims tend to be taller than the younger ones. We now examine each of these trends in more detail.

Firstly, there is a differentiation in all Anaro 3 squares at around $30-50 \mathrm{~cm}$ between the presence of circle-stamped pottery below this depth and its complete absence above. The C14 dates also form two groups, one in the first millennium BC, the other in the mid-first millennium AD and separated from the former by a 400 year gap. This differentiation is the main reason for separating the Anaro 3 rim sherd drawings into two groups, above and below $40 \mathrm{~cm}$. However, apart from the disappearance of decoration there is considerable continuity in vessel and rim shapes from bottom to top of the Anaro site.

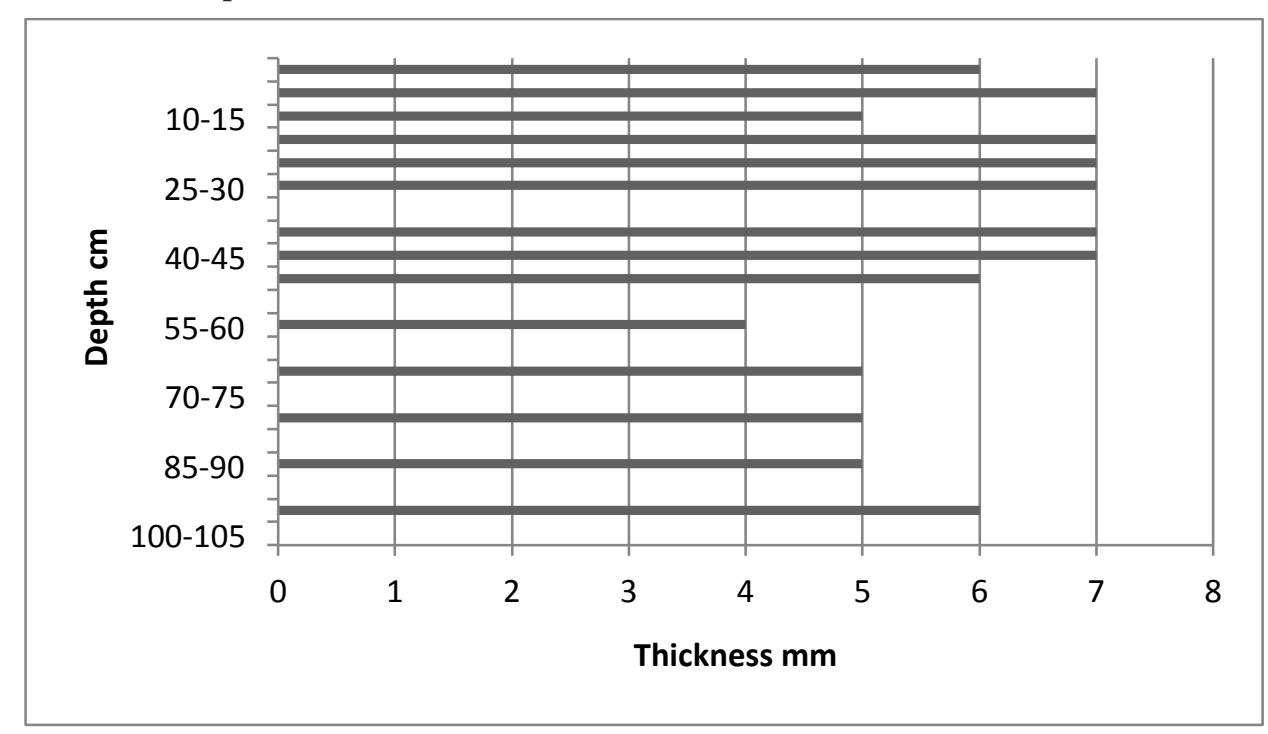

Figure 6.5. Modal body sherd thicknesses ( $\mathrm{mm}$ ) at Anaro 3 (2004) by depth from surface. Samples were not measured from missing spits.

Secondly, average single sherd weights in the top layers of all squares are much greater, sometimes by a factor of three, than in the lower layers. This could reflect the length of time they have spent in the ground (less time = less breakage and weathering?). Body sherd thickness does not seem to be a factor here since there is very little change in this from top to bottom of the site (Fig. 6.5). Regardless of the cause, this fairly smooth fall-off in sherd mass with depth is a very useful variable for identifying potential disturbance. For instance, in most squares the fall-off of average sherd size from top to bottom is fairly regular, except in 3B, where it can be seen from Table 6.1 that the bottom 70 to $90 \mathrm{~cm}$ depth has unusually large sherds. Three of the four $\mathrm{C} 14$ dates from this zone also conflict with the three older dates from squares 3 (2004) and 3A (Table 5.1). This might reflect disturbance in square $3 \mathrm{~B}$, involving a movement of younger material downwards in the profile, and had this circumstance been noted when we sent in the C14 samples to ANSTO in Sydney for dating we would probably have picked another square different from 3B. Hindsight, unfortunately, is rarely much help in such circumstances. In this regard it is important to note that $3 \mathrm{~A}$ is inside the rockshelter, thus secure from tillage and tree root activity, and has two credible 
C14 dates, whereas 3 and $3 \mathrm{~B}$ are outside and more vulnerable in this regard. The better-protected $3 \mathrm{~A}$ has a very even distribution of sherds and a regular fall off in sherd mass, suggesting that it has suffered little disturbance. The circle-stamped sherds in $3 \mathrm{~A}$ are also remarkably homogeneous in their decorative motifs (to be described later), and show no signs of admixture with the other styles that occur in other parts of the Anaro site.

Thirdly, body sherd thicknesses were measured for several spits in the square Anaro 3 (2004). They range from 2 to $15 \mathrm{~mm}$, with the vast majority being in the 5 to $10 \mathrm{~mm}$ range. The modal values do not vary sufficiently to hint at any significant change through time, although there is a tendency for older sherds to be slightly thinner, as can be seen in Fig. 6.5.

The modal value for body sherd thickness at Anaro 2 was also 5, similar to the lower levels in the Anaro 3 squares. But at Anaro 1A, where all the sherds appeared to be very recent, the mode was between 7 and $9 \mathrm{~mm}$ in all levels. So there probably was an increase in average body sherd thickness towards the end of Anaro and Itbayat prehistory, at a time when Chinese imports were available for food serving and local earthenware would probably have served more kitchen-based functions, thus needing to be thicker and heavier. As can be seen in Fig. 6.5, in Anaro 3 (2004), modes of $7 \mathrm{~mm}$ occur only in the top half of the stratigraphy.

Fourthly in this examination of trends, the external heights of the everted rims provide another useful variable for looking at change through time. This rim height metric has been discussed already for Torongan and Reranum. The external heights are measured from the vessel lip down the exterior of the rim to the point where the neck passes through verticality. In Tables 6.1 and 6.2 they are listed by percentage of everted rims over $3 \mathrm{~cm}$ tall for each layer in Anaro 3A, 3B, and $3 \mathrm{C}$, and it is very clear that such rims do indeed become taller with increasing depth/age, even if the progression is slightly irregular. This value does not correlate with orifice diameter, and at Mitangeb the narrow-necked vessels that might have been used for liquids have taller necks then the wider cooking pots. It is clear that both time and function have their roles to play, but the metric appears to be useful as a time indicator, even if its exact functioning is not understood.

The importance of this tallness value can be seen in wider context. The percentages of rims over $3 \mathrm{~cm}$ tall for a number of other dated Batanes sites, apart from Anaro 3, are shown in Table 6.3, in each case from the whole measurable assemblage (i.e. rims that have adjoining necks). Despite minor fluctuations it is clear that there is a definite progression starting with the tall rims in the earlier sites of Torongan, Reranum and Sunget (with some up to $6 \mathrm{~cm}$ high in the latter two cases, but not at Torongan). We can add to this early phase the Anaro 5 undated but typologically early surface collection (1500-1000 BC? see Fig. 6.4 bottom left), and the Savidug Dune Site basal phase (Sunget and Savidug pottery is described below). This early tendency towards tallness is followed by a sharp decrease that seems to be fairly well marked by $500 \mathrm{BC}$ (Savidug jar burial phase and Anaro 3). As noted, this can also be seen in the progressive decrease in percentages for this variable from bottom to top in the Anaro 3 squares (Tables 6.1 and 6.2) and the Savidug Dune Site trench QR/7-9 (Table 6.6). This shortening of rims through time can also be observed in the Sunget to Naidi sequence on Batan Island, and remarkably in the Neolithic pottery sequence from the sites of Minanga Sipakko and Kalumpang in the Karama valley in West Sulawesi, Indonesia (Anggraeni et al. in press). The significance of this observation involving Sulawesi need not be emphasised here, but in terms of broader Austronesian migration patterns it is of enormous importance. Interestingly, the Taiwan Middle Neolithic assemblages from Donghebei and Chaolaiqiao shown in Fig. 6.2 also have large proportions of eversions over $3 \mathrm{~cm}$ tall, linking them closely to Torongan and Reranum. 


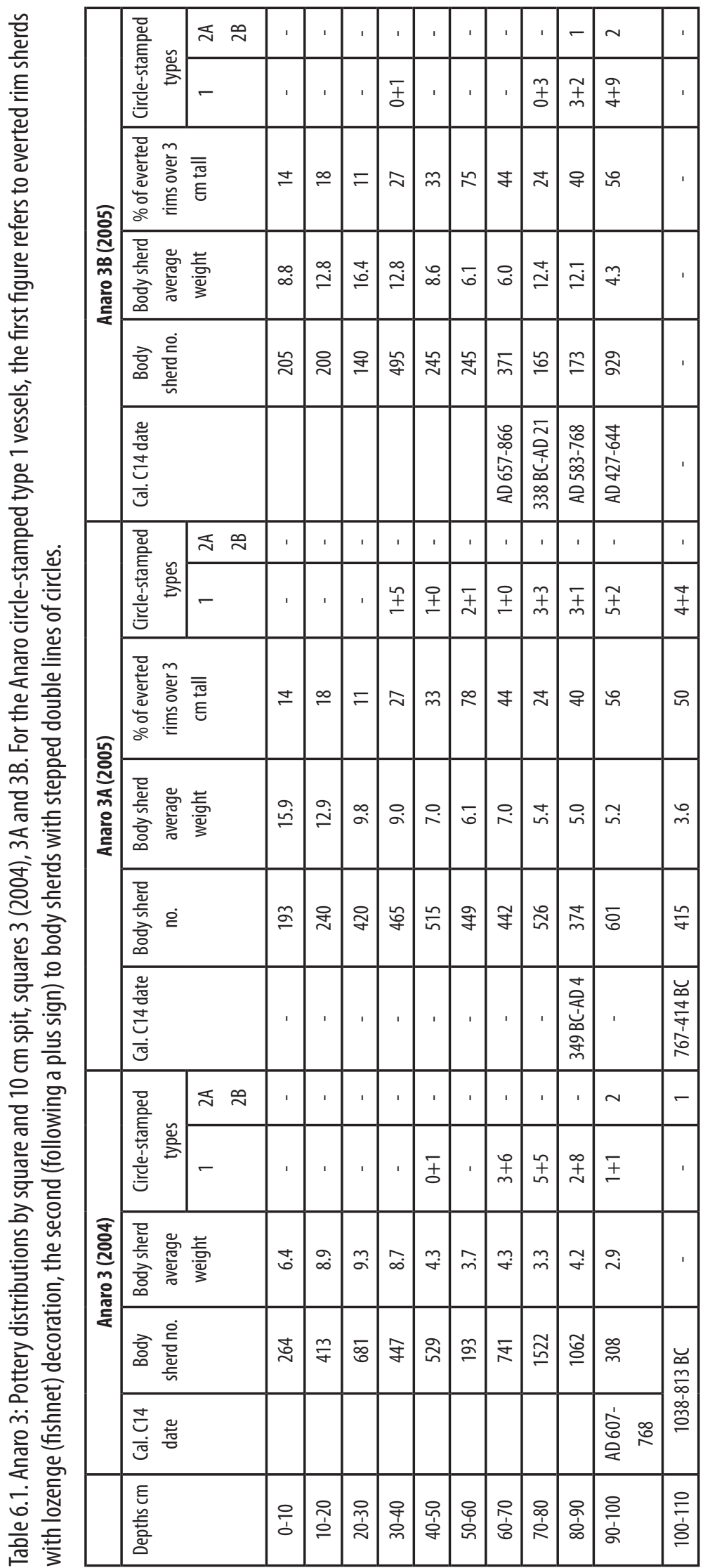


Table 6.2. Anaro 3: Pottery distributions by square and $10 \mathrm{~cm}$ spit, squares $3 \mathrm{C}, 3 \mathrm{~F}$, and distributions of specific sherd classes. For the Anaro circle-stamped type 1 vessels, the first figure refers to everted rim sherds with lozenge (fishnet) decoration, the second (following a plus sign) to body sherds with stepped double lines of circles. $A=$ incised sherds; $B=$ sherd with parallel impressed ribs; $C=$ corrugated rims (as at Mitangeb on Siayan); $D=$ "phallic" lug; $E=$ pottery figurine fragment; Fig. 6.9B.

\begin{tabular}{|c|c|c|c|c|c|c|c|c|c|c|c|c|c|}
\hline \multicolumn{6}{|c|}{ Anaro 3C (2005) } & \multicolumn{3}{|c|}{ Anaro 3F (2006) } & \multicolumn{5}{|c|}{ All squares - specific classes } \\
\hline \multirow[t]{2}{*}{ Depths cm } & \multirow[t]{2}{*}{$\begin{array}{c}\text { Body sherd } \\
\text { number }\end{array}$} & \multirow{2}{*}{$\begin{array}{c}\text { Body sherd } \\
\text { average } \\
\text { weight }\end{array}$} & \multirow{2}{*}{$\begin{array}{c}\% \text { everted } \\
\text { rims over } 3 \\
\mathrm{~cm} \text { tall }\end{array}$} & \multicolumn{2}{|c|}{$\begin{array}{c}\text { Circle-stamped } \\
\text { types }\end{array}$} & \multirow[t]{2}{*}{$\begin{array}{c}\text { Body sherd } \\
\text { number }\end{array}$} & \multicolumn{2}{|c|}{$\begin{array}{l}\text { Circle-stamped } \\
\text { types }\end{array}$} & \multirow[t]{2}{*}{ A } & \multirow[t]{2}{*}{ B } & \multirow[t]{2}{*}{ C } & \multirow[t]{2}{*}{ D } & \multirow[t]{2}{*}{ E } \\
\hline & & & & $1 \mathrm{~A}$ & $\begin{array}{l}2 A \\
2 B\end{array}$ & & $1 \mathrm{~A}$ & $\begin{array}{l}2 A \\
2 B\end{array}$ & & & & & \\
\hline $0-10$ & 83 & 12 & - & - & - & 32 & & & & & & & \\
\hline $10-20$ & 284 & 11.3 & - & - & - & 59 & & & & & & & \\
\hline $20-30$ & 536 & 12.2 & 7 & - & - & 160 & & & & & & & \\
\hline $30-40$ & 518 & 6.6 & 8 & $2+2$ & - & 235 & & & & & & & \\
\hline $40-50$ & 449 & 5.4 & 38 & $1+0$ & - & 30 & & & & & 1 & & \\
\hline $50-60$ & 1376 & 5.3 & 33 & $6+10$ & - & 109 & $0+1$ & & & & & & \\
\hline $60-70$ & 835 & 5.1 & 40 & $3+11$ & - & 97 & $0+1$ & & & & 1 & & \\
\hline $70-80$ & 482 & 5.2 & 20 & - & 1 & 107 & $1+4$ & 2 & 2 & 1 & & 1 & \\
\hline $80-90$ & 30 & 4.1 & no rims & - & 3 & 93 & & 3 & 1 & & & & 1 \\
\hline $90-100$ & - & - & - & - & - & & & & & & 1 & & \\
\hline $100-110$ & - & - & - & - & - & & & & 1 & & & & \\
\hline
\end{tabular}

Table 6.3. The decrease in the proportions of everted rims over $3 \mathrm{~cm}$ high in Batanes sites between $2000 \mathrm{BC}$ and AD 600 . See also the more detailed information on Anaro rim heights in Table 6.1, and the Savidug analysis by Alexandra de Leon, below.

\begin{tabular}{|l|c|c|}
\hline Site and approximate date & No. everted rims & \% over 3 cm tall \\
\hline Torongan Cave, Itbayat, 2000 to 1200 BC & 53 & 68 \\
\hline Reranum Cave, Itbayat, 2000 to 1000 BC & 35 & 74 \\
\hline Sunget, Batan (1200-800 BC) & 20 & 80 \\
\hline Savidug basal phase, Sabtang (1200-500 BC) & varies by spit & up to 83 \\
\hline Savidug jar burial phase, Sabtang (500-1 BC) & varies by spit & up to 30 \\
\hline Batan Island, Naidi Phase assemblages (200 BC-AD 500) & 27 (Fig. 6.22) & 23 \\
\hline Anaro 2, Itbayat, excavation and surface collection (500 BC-AD 500) & 118 & 20 \\
\hline Anaro 6, Itbayat (AD 1-600) & 134 & 10 \\
\hline Mitangeb, Siayan (AD 1-600) & 51 & 8 \\
\hline
\end{tabular}

\section{The sequence of decorated (circle-stamped) pottery at Anaro}

The situation with respect to decorated pottery in the Anaro 3 squares is most interesting. As can be seen in Tables 6.1 and 6.2, all decorated sherds are confined basically to the bottom half of each excavated square in this area, with first appearances always below $30 \mathrm{~cm}$. Apart from a few rare incised sherds and one ribbed one, virtually all decoration in the Anaro 3 excavated squares is a standardised creation utilising rows of stamped circles, similar to the circle stamping at Sunget on Batan (described below), but also intriguingly different from Sunget in its preferred motifs. Enough large sherds, including rims, necks and bodies, survive from the excavated Anaro 3 squares to indicate that only one decorated vessel type existed during most of the time span represented by the deposits located in this area (Fig. 6.6 top), although this is certainly not true for 
the whole site. The Anaro 3 excavated rims, all everted and all over $3 \mathrm{~cm}$ tall, some with external lip grooves, have external lozenge or net-like lattice patterns built from single rows of circles. Upper bodies directly below the rims carry a pattern built from close-set parallel paired rows of circles, forming horizontal bands with low steps at intervals. We term this kind of vessel and decoration, in combination, Anaro circle-stamped type 1. Perhaps it was the signature style for the nephrite workers who clearly lived somewhere near this area of the site at the same time as this pottery was being made and the Anaro 3 deposits were being laid down. All Anaro circle-stamped type 1 rim sherds are everted, and no open bowls with direct rims appear to have been decorated in this exact style. Tables 6.1 and 6.2 present data on the distributions of circle-stamped pottery sherds in the analysed squares Anaro 3 (2004), 3A, 3B, 3C and 3F. In 3A especially, all the decorated sherds recovered, a total of 36, belong to Anaro circle-stamped type 1 vessels, all with everted rims.

However, the excavated layers at Anaro 3 clearly do not give the full sequence for the Anaro site as a whole, at least not according to the voluminous surface finds. There is another very common form of decoration which occurs in large quantities in the surface collections, and sometimes also very rarely at the base of the Anaro 3 excavated squares. This form of decoration, of single rather than parallel rows of circles creating especially meander and zigzag motifs, defines vessels of Anaro circle-stamped types $2 A$ (everted rim vessels with round or carinated bodies) and $2 B$ (direct-rimmed open bowls). These motifs are quite different from the lozenge motifs and double rows of circles on the Anaro circle-stamped type 1 vessels. Many examples of circle-stamped type $2 \mathrm{~A}$ and $2 \mathrm{~B}$ vessels, all surface finds collected from below the eastern side of the hill (the opposite side from Anaro 3), are illustrated in the lower section of Fig. 6.6. In Table 6.1, columns headed $2 \mathrm{~A} / 2 \mathrm{~B}$, it can be seen that sherds of these two types occur only in very small numbers in the bottom layers of squares 3 (2004), 3B, 3C and 3F, suggesting a temporal priority for Anaro circlestamped type $2 \mathrm{~A} / 2 \mathrm{~B}$ vessels over the younger Anaro circle-stamped type 1.

Fig. 6.7 shows surface collected examples of a third class of rims, classified as Anaro circle-stamped types $3 A$ (everted) and $3 B$ (direct), again all collected from the lower slopes of the north side of Anaro Hill, where remnants of early layers now destroyed have slid down and come to rest. These form a category of stamped circle designs which are neither of circle-stamped types 1 nor 2 , so are hence defined as a kind of residual entity, but one that may be significant nevertheless. Absolutely no sherds of Anaro circle-stamped type 3 were found in the Anaro 3 excavated squares.

To summarise, three design styles of circle-stamped pottery with associated vessel types can be identified for Anaro, the first two being successive in time, as follows:

1. (Younger) This consists of the linked lozenge and double-row-of-circle designs that characterise the Anaro 3 excavated squares, and apparently the phase of the most intensive nephrite working at Anaro (Fig. 6.6 top). As noted, this style is termed Anaro circle-stamped type 1, and all recovered vessels have everted rims.

2. (Older) This consists of the single-row-of-circle open meander and zigzag designs that occur basally in very small numbers in the Anaro 3 excavated squares, mostly towards the base in Anaro 2, and very commonly in surface collections from AN2 and AN5 (Fig. 6.6 lower). This style incorporates Anaro circle-stamped type 2A (everted rim) and 2B (direct rim) vessels.

3. (Equivocal chronology, but probably older than Anaro circle-stamped type 1) This consists of unique designs, most so far found on single sherds found only on the surface at Anaro. Some of the multiple-row-of-circle designs, such as the two labelled A and B in Fig. 6.7, are paralleled very closely at Sunget on Batan and the Savidug Dune Site on Sabtang, both c.1200-800 BC. This style is present on Anaro circle-stamped type 3A (everted rim) and 3B (direct rim) vessels. 


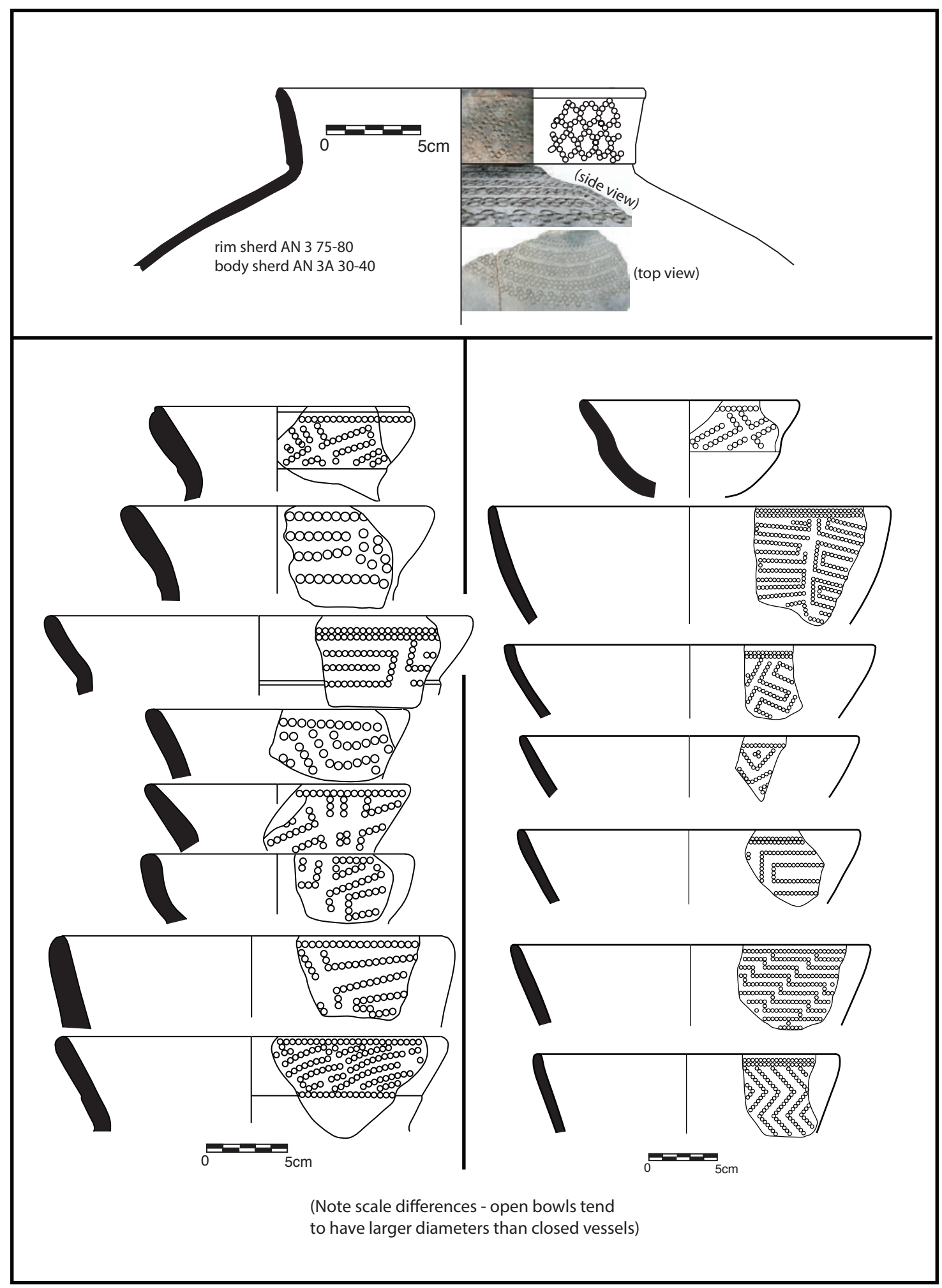

Figure 6.6. Top: reconstruction of an Anaro circle-stamped type 1 vessel, the type found in close association with nephrite working in the lower layers of Anaro 3 . Lip diameter $21 \mathrm{~cm}$. Bottom: surface finds of rims of Anaro circle-stamped types $2 \mathrm{~A}$ and $2 \mathrm{~B}$, with rectangular meander designs.

Source: Peter Bellwood. 


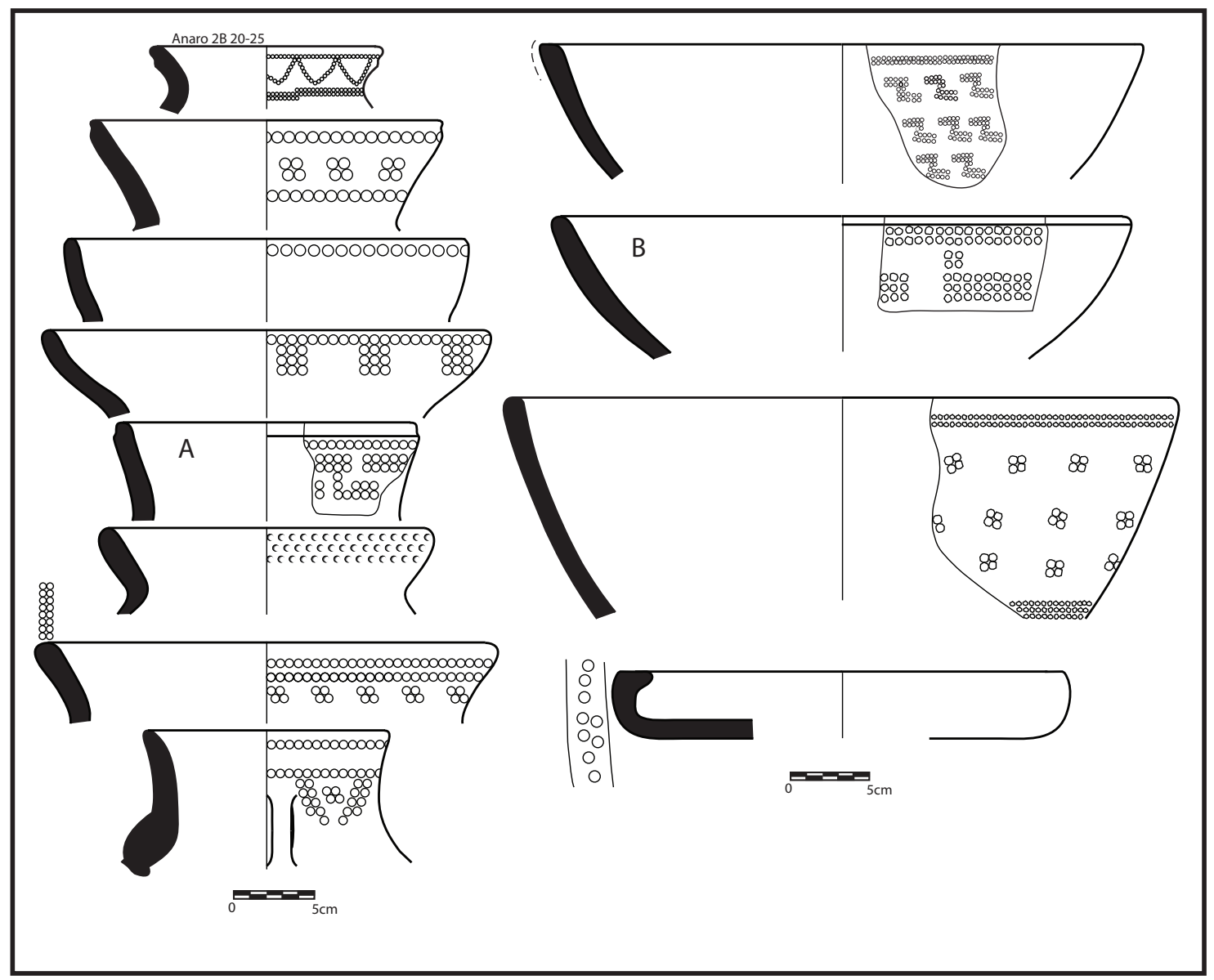

Figure 6.7. Surface finds of rims of Anaro circle-stamped types $3 \mathrm{~A}$ and $3 \mathrm{~B}$, with varied designs. Fifth down on the left hand side is paralleled in the Sunget assemblage from Batan. The example at top left was excavated in Anaro 2.

Source: Peter Bellwood.

One implication of the above distribution is that the surviving excavated archaeological layers on the terraces and top of Anaro contain pottery dating only to the past 3000 years at the most, given the rarity of types $2 \mathrm{~A}$ and $2 \mathrm{~B}$ and the total absence of type $3 \mathrm{~A}$ and $3 \mathrm{~B}$ sherds in the excavations. Once-existing older layers and their contained pottery were perhaps eroded off these areas prior to this date. These older materials can now be found only as surface finds down the hill slopes.

As will be discussed below, "phallic" shaped lugs are common in surface collections from Anaro (Fig. 6.8) and are sometimes decorated with the same stamped circle motifs as Anaro circlestamped type $2 \mathrm{~A}$ and $2 \mathrm{~B}$ vessels. Their rarity in the excavated layers in the Anaro 3 squares is therefore not surprising (only one was found), since they may be older in date. The single human figurine arm from the base of Anaro square $3 \mathrm{~F}$ has tattoo decoration of rows of single circles (Fig. $6.9 \mathrm{~B}$ ), relating it to the Anaro circle-stamped types $2 \mathrm{~A}$ and $2 \mathrm{~B}$ rather than the Anaro circlestamped type 1 vessels.

\section{The Anaro 2 pottery}

Anaro 2 was only a $3 \times 1 \mathrm{~m}$ excavation, quite shallow, and contained what appeared to be mixed deposits (doubtless cultivated) above and below a single C14 date of AD 53-238 (Table 6.4). The sherds in general are very small and eroded, with low average weights. Most of the occupation deposit that once existed here has been eroded away down the side of the hill, and in the fields 
cleared for cultivation below the Anaro 2 excavation in 2004 we found large numbers of quite large rims, decorated sherds, stone adzes and pieces of slate. Anaro 2 has a mixed assemblage of decorated sherds, unlike the far more homogeneous Anaro 3, with Anaro circle-stamped type 1 and $2 \mathrm{~A} / 2 \mathrm{~B}$ sherds represented throughout. Anaro 2 is thus unlikely to represent a single phase of occupation. However, the Anaro circle-stamped type 1 rims do appear to have a higher stratigraphic centre of gravity than the Anaro circle-stamped type 2 rims (Table 6.4), and this situation in general accords with that in Anaro 3. For instance, 10 of the 15 Anaro circle-stamped type 2A/2B rims occur below the C14 dated level of AD 53-238.
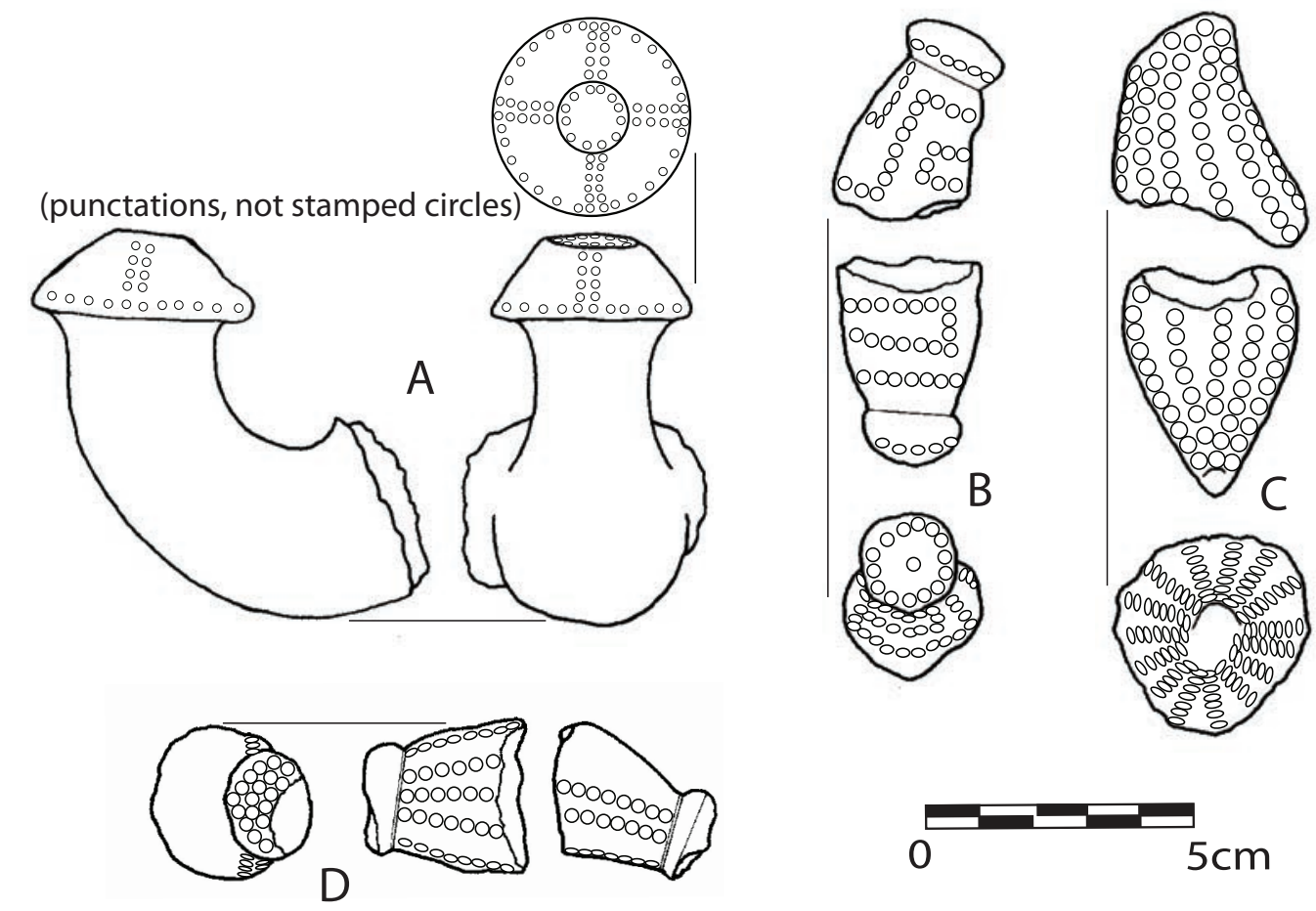

Figure 6.8. Examples of decorated pottery appendages from Anaro, all surface finds.

Source: Peter Bellwood.

Table 6.4. Pottery distribution by $10 \mathrm{~cm}$ spit at Anaro 2. For the Anaro circle-stamped type 1 vessels, the first figure refers to everted rim sherds with lozenge (fishnet) decoration, the second following a + sign to body sherds with stepped double lines of circles.

\begin{tabular}{|c|c|c|c|c|c|c|c|}
\hline \multirow[t]{2}{*}{ Anaro 2} & \multirow[t]{2}{*}{ Cal. C14 date } & \multirow{2}{*}{$\begin{array}{c}\text { Body sherd number } \\
\text { (Excavation squares Anaro 2A } \\
\text { and 2B only) }\end{array}$} & \multirow[t]{2}{*}{$\begin{array}{c}\text { Body sherd } \\
\text { average weight }\end{array}$} & \multirow[t]{2}{*}{$\begin{array}{c}\text { \% everted rims } \\
\text { ove }\end{array}$} & \multicolumn{2}{|c|}{$\begin{array}{l}\text { Circle-stamped } \\
\text { types }\end{array}$} & \multirow[t]{2}{*}{$\begin{array}{l}\text { Incised } \\
\text { sherds }\end{array}$} \\
\hline & & & & & 1 & $\begin{array}{l}2 A \\
2 B\end{array}$ & \\
\hline $0-10$ & & 767 & 4.8 & 29 & $0+2$ & & 1 \\
\hline $10-20$ & AD 53-238 & 2879 & 3.9 & 9 & $0+1$ & 5 & 1 \\
\hline below 20 & & 1959 & 3.7 & 18 & $1+1$ & 10 & 1 \\
\hline
\end{tabular}




\section{The Anaro 6 pottery}

Anaro 6 was a 1 by $1 \mathrm{~m}$ excavation in a cave that produced a large amount of pottery, from the surface down to about $120 \mathrm{~cm}$, very similar to that from Mitangeb on Siayan Island (to be described below). Anaro 6 has similar corrugated rims to Mitangeb, but like Mitangeb lacks vessel knobs and figurines, nephrite and slate. Four Anaro circle-stamped type 1 decorated body sherds were found, but in a total of 2381 body sherds these are rather negligible. Interestingly, three monochrome Chinese sherds (Song or Ming, probably) were also found between 30 and $60 \mathrm{~cm}$. It is not clear how the latter relate to the date of the assemblage as a whole, given that absolutely no Chinese sherds were found at Mitangeb. Anaro 6 clearly does not have a great deal of stratigraphic integrity and average sherd weights in fact become greater with depth (Table 6.5), suggesting perhaps a degree of stratigraphic inversion reflecting erosion and redeposition inside the cave of an uphill deposit from the surface downwards.

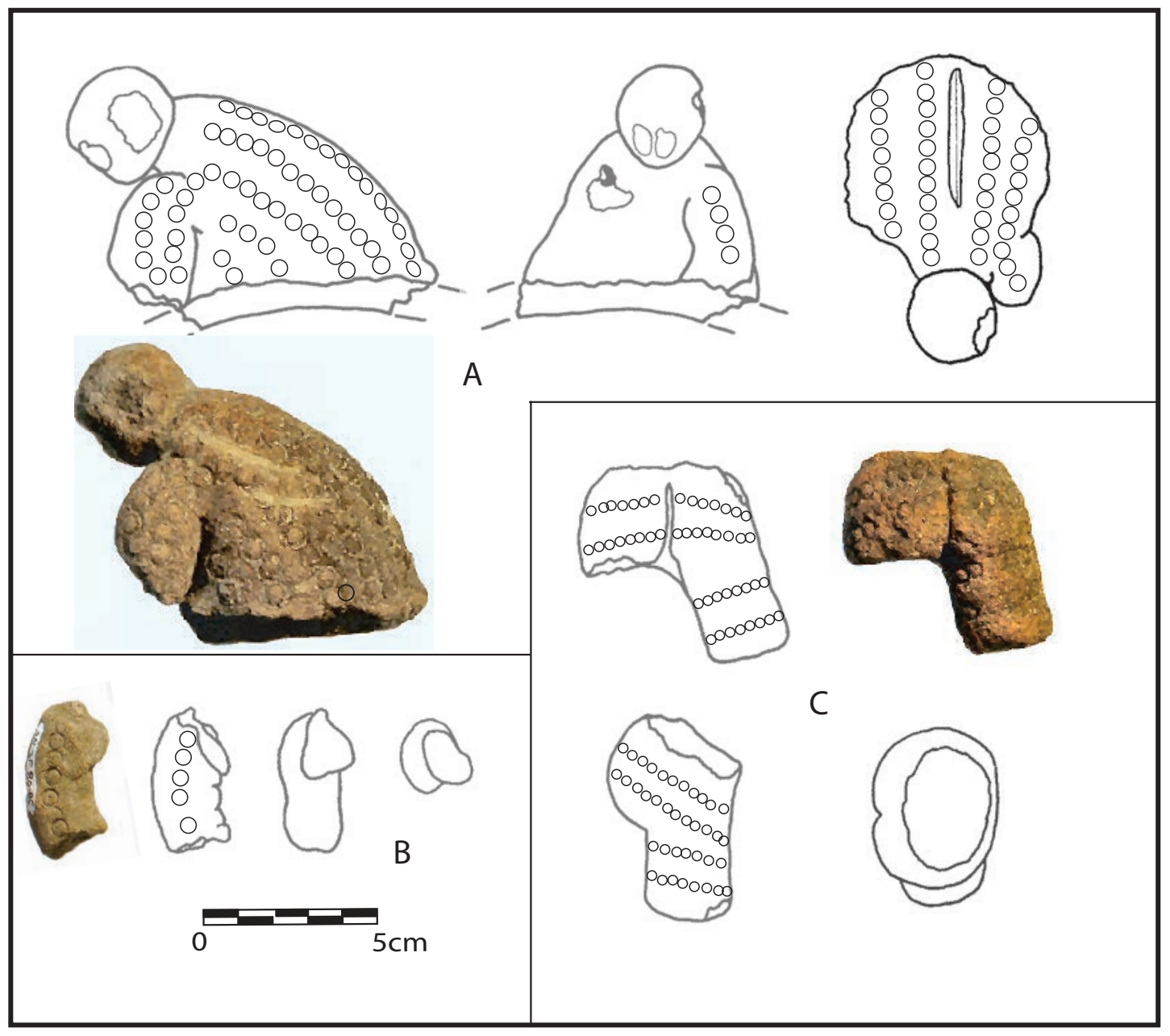

Figure 6.9. Decorated human figurine fragments from Anaro. A was clearly affixed to a pot as a handle (surface find). B is an arm similar to that attached to A, excavated from Anaro $3 \mathrm{~F} 80-85 \mathrm{~cm}$, and thus perhaps $2500-3000$ years old. C is a tattooed buttocks area and upper right leg (surface find). 
Table 6.5. Pottery distribution by $10 \mathrm{~cm}$ spit at Anaro 6 .

\begin{tabular}{|c|c|c|c|c|}
\hline Anaro 6 & Body sherd number & Body sherd average weight & Circle-stamped type 1 & Chinese \\
\hline $0-20$ & 140 & 6.4 & 1 & \\
\hline $20-30$ & 285 & 6.3 & & \\
\hline $30-40$ & 129 & 8.2 & & 1 \\
\hline $40-60$ & 115 & 8.4 & & 2 \\
\hline $60-70$ & 258 & 7.8 & & \\
\hline $70-80$ & 277 & 10.5 & & \\
\hline $80-90$ & 385 & 7 & & \\
\hline $90-100$ & 426 & 10.1 & & \\
\hline $100-110$ & 228 & 10.9 & & \\
\hline $110-120$ & 119 & 9.2 & & \\
\hline $120-130$ & 22 & 6.6 & & \\
\hline
\end{tabular}

The Mitangeb pottery (c.AD 1-600)

The reconstructable rims excavated from Mitangeb, with sufficient circumference to determine diameter and rim height, are illustrated in Figs 6.4 (bottom right) and 6.10. It is obvious that there are two classes in terms of rim diameter, one about $12 \mathrm{~cm}$ across the mouth and perhaps for storing liquids, the other about $16 \mathrm{~cm}$. The corrugated rims shown in Fig. 6.10 all belong to the smaller diameter group. Most of these vessels have short everted rims - only $18 \%$ are longer than $2 \mathrm{~cm}$ and only $8 \%$ longer than $3 \mathrm{~cm}$. This distinguishes this assemblage very clearly from the earlier and taller rims from sites such as Torongan, Reranum, Savidug on Sabtang and Sunget on Batan.

The remarkable similarity with contemporary vessels from Anaro suggests that the Mitangeb pottery was perhaps taken to Siayan from Itbayat, containing food and water for use on the island by groups engaged in some exploitative activity such as fishing or catching turtles. Surprisingly, the whole Mitangeb assemblage has only one example of a direct-rimmed open serving bowl, shown in Figure 6.4. Such vessels are very common in sites on the larger islands, and this situation may indicate that elegant food serving was not considered a priority in the difficult circumstances of life on Siayan.

Mitangeb is of great interest because it has absolutely no examples of full circle stamping, apart from the rather different horseshoe stamps shown on the top left sherd in Figure 6.10. Red slipping is present, as it is through the whole Batanes ceramic sequence, but it is also quite rare in this site - Figs 6.4 and 6.10 show only two red-slipped rims, one corrugated. Figure 6.10 also shows a corrugated foot ring from a surface location below Anaro 2, together with some excavated examples from Anaro 3 and 6 . The foot ring is added to show that such vessels sometimes had them, even though none were found at Mitangeb.

At this point it can be noted that the Mitangeb site offers a clear and unambiguous time horizon lasting for a short period during the early first millennium AD, perhaps AD 1-600, by which time circle stamping was completely absent, but corrugated rims identical to those in the middle layers at Anaro 3 were present. Mitangeb also has no Taiwan slate or nephrite artefacts. Anaro 6 has almost identical pottery, again with corrugated rims, but almost no circle stamping and no nephrite. Whether this apparent absence of nephrite at this time reflects reality, or just small sample size, remains unclear, and perhaps much should not be made of this observation. There is actually no reason to assume that nephrite movement ceased at this time. 


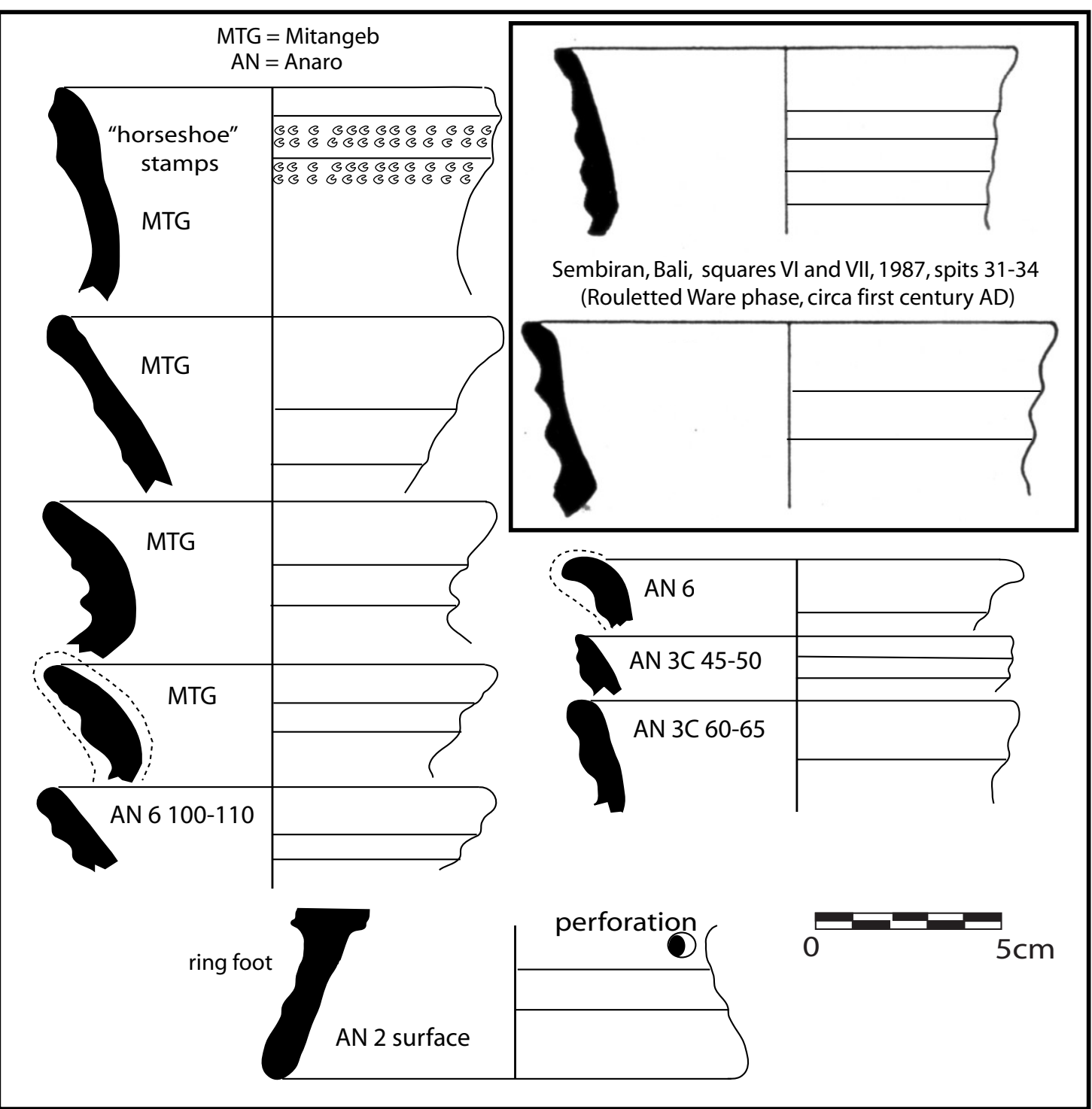

Figure 6.10. Left side: Mitangeb and Anaro corrugated rims, all $12 \mathrm{~cm}$ diameter and probably from water jars. Dotted lines around rims = red slip. Right side: rims and a whole pot from Sembiran, North Bali, from Ardika 1991, Fig. 5.4.

Source: Peter Bellwood.

The corrugated rims, in fact, require a further commentary since they could be very significant markers of a time range between $\mathrm{AD} 1$ and 500. They occur in the early Indic-contact phase sites of Sembiran and Pacung in northern Bali, dating generally to around 2000 years ago (Ardika and Bellwood 1991), and a series drawn in the unpublished PhD thesis of I Wayan Ardika (1991, page 98) are reproduced here in Figure 6.10. More have been recovered from these two very important sites during current research by Ambra Calo (pers. comm.). Corrugated rims and even red-slipped and circle-stamped pottery are known also to come from the site of Ying-pu in western Taiwan, according to the collections of the National Museum of Natural Science in Taiwan, but in this case the dating is not clear.

The corrugated rim form is easy to recognise, and seemingly concentrated in its occurrence to layers in Batanes and Bali dating from the early first millennium AD. Is it a reflection of interisland contact during the early period of trade stimulated by contacts with India? Corrugated 
rims of the exact Mitangeb and Sembiran types do not seem to be present in India, although it is impossible to check every museum collection and published report. But corrugation is present on rims and necks from the famous site of Arikamedu in Tamil Nadu (e.g. Wheeler et al. 1946: Fig. 27 no. 63b, and various examples in Figs 34 and 35). Whether this is all coincidence remains to be seen, but at least the resemblances are worthy of comment. Could it be that they reflect in some way the trade in Taiwan nephrite to be described by Hsiao-chun Hung in chapter 9 (allowing, of course, that Taiwan nephrite has not yet been positively identified in either India or anywhere in Indonesia, or for that matter in Anaro 6 or Mitangeb)?

\section{The Anaro pottery surface finds}

The surface finds made at Anaro have been quite staggering in quantity, spread like a carpet over the steep slopes that surround the limestone summit and especially visible whenever fields are cleared for planting. Many finds were made by the field teams, others by the family of Rodobaldo Ponce, owner of some of the land on the eastern side of the hill. Non-pottery artefacts such as adzes, nephrite and slate, together with spindle whorls, are described in chapters 7 to 9. This section is concerned only with the pottery sherds.

The richest lower-slope collection areas are labelled on Fig. 2.13 as AN1, AN5, AN2/4, and KX 2-4 (Kaxanggan is the land name for the western side of the hill). The most coherent and concentrated collections came from AN 2/4 and 5, the former partly fallen down from the terrace area excavated at Anaro 2 in 2004. Much of the material from AN 2/4 obviously resembles that from the Anaro 2 excavation, and some sherds from above and below, albeit weathered, look as if they could be from the same pots. Unfortunately, the shallowness and evident disturbance of the Anaro 2 excavation stratigraphy by cultivation makes it difficult to regard the material from here as a single chronological assemblage.

AN 5, however, was especially interesting because many of the rims from there resemble those from Torongan, Reranum and Sunget, i.e. sites with ages in excess of 3000 years. Some are shown in Fig. 6.4, at bottom left. These rims are tall, often internally concave, and some vessels had high foot rings, as at Reranum. Large numbers of decorated sherds were collected from AN 2/4 and 5 , of which the vast majority belong to Anaro circle-stamped types $2 \mathrm{~A}$ and $2 \mathrm{~B}$. Anaro circlestamped type 1 vessels, so common at Anaro 3, are rare, but never totally absent. It is difficult to give statistics for surface collected materials since we never collected absolutely everything that was visible (car boot-loads would have resulted), and so the relationship between a collected sample size and the background universe cannot be precisely known.

\section{Anaro pottery handles and other appendages}

Mostly surface rather than excavated finds, the vessel handles and/or appendages at Anaro consist of the following categories:

1. Cylindrical projections, possibly handles, that have a variety of "phallic" shapes. Some of these have single rows of circle-stamped decoration like that on the Anaro circle-stamped 2A and 2B sherds (Figs 6.8 B, D; 6.11 middle row).

2. Human figurines with single rows of tattoo-like circle-stamped decoration (Fig. 6.9). An arm of one of these was excavated from Anaro 3F, 80-85 cm (Fig. 6.9B).

3. Handles, of both loop and lug forms, the former resembling handles from Sunget (1200-800 BC) (Fig. 6.11 top row). One is associated with circle-stamped decoration (top right).

4. A variety of blunt, fat and round projections, some with single rows of circle-stamped decoration (Fig. $6.8 \mathrm{C}, 6.11$ bottom row). 
Chronologically, these appendages would appear in general to be older than $500 \mathrm{BC}$ at Anaro, given the similarities in decoration with Anaro circle-stamped sherds of types 2 and 3. They are absent in the AD 1-600 site of Mitangeb, and contemporary or later Anaro 6 has only a single undecorated phallic knob, at $60-70 \mathrm{~cm}$ depth.

\section{The Itbayat pottery sequence: Anaro and Mitangeb through time}

To build up a cultural chronology for Anaro and Mitangeb, it is necessary to work from known and well-dated assemblages into the relative unknown. Thus, commencing with Mitangeb in the early first millennium $\mathrm{AD}$, we have a well-defined phase with plain pottery with short everted rims, two categories of diameter (for liquid storage and cooking?), almost no red slip, no surface decoration, and a common presence of the important chronological marker category of corrugated rims. Nephrite and slate are both absent, although the Mitangeb excavation was small and there is no reason to assume a total absence of contact with Taiwan at this time. Allied with Mitangeb we also have most of the contents of Anaro 6, plus the middle layers of Anaro 3 (albeit rather indistinctly in this case). The four C14 dates that range from AD 400 to 900 from Anaro 3 and $3 \mathrm{~B}$ presumably relate to this phase, despite the fact that all of them are in stratigraphic situations that suggest disturbance. All are on food residues from inside the bases of pots, by definition a vessel location that was never decorated, thus making it impossible to know if the sherds came from pots that ever carried decoration (this is a problem with all food residue AMS dates from pottery, for obvious reasons).

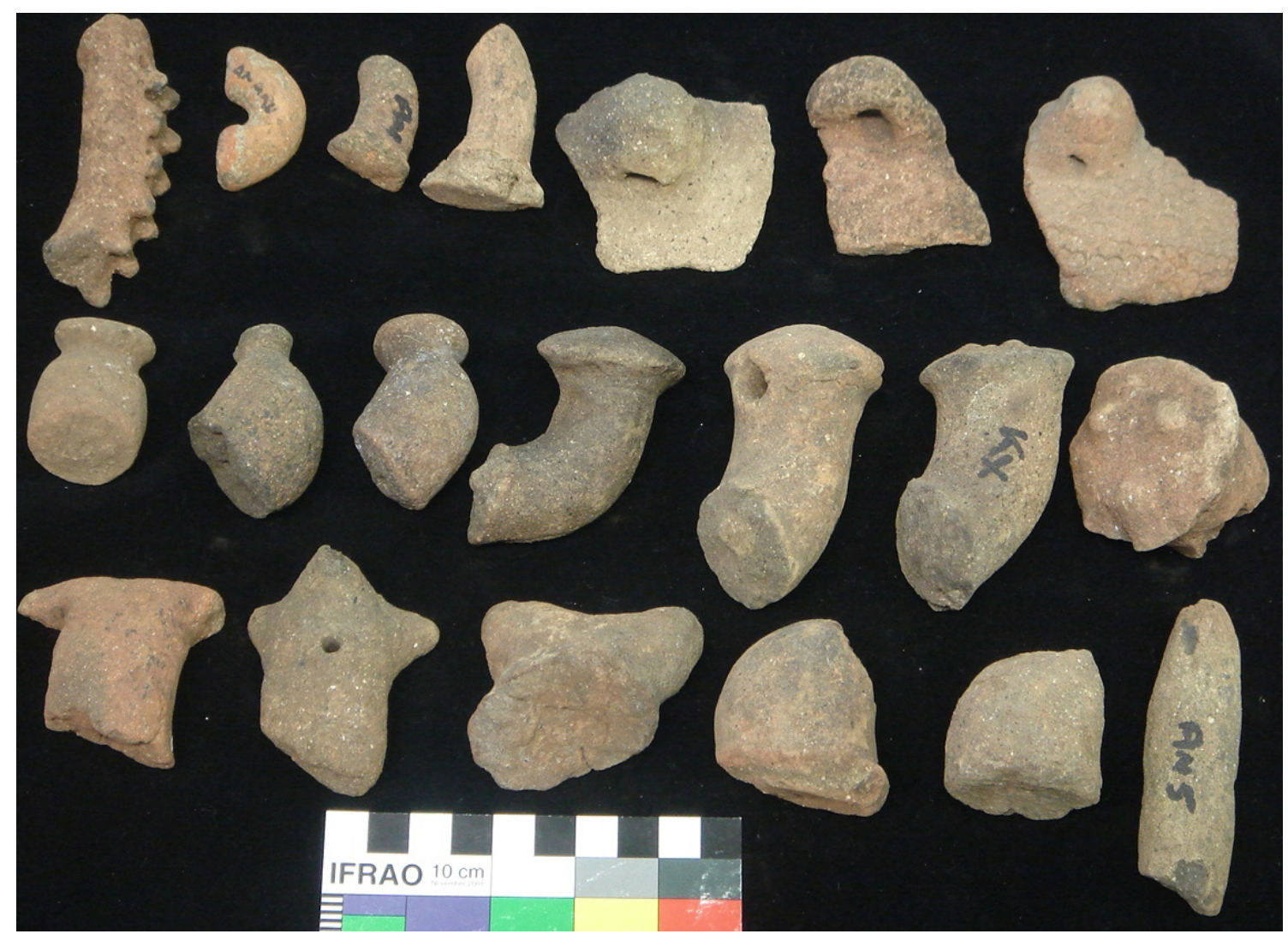

Figure 6.11. A range of pottery appendages from Anaro, all surface finds. Top row: handles (loop and lug), specimen on right on a circle-stamped sherd. Middle: knobs of roughly "phallic" shape, the two at right with subsidiary distal bumps. Bottom: angular, round and fat projections, presumably pottery handles. 
If we then move to the Anaro 3 excavated sequence, we come to an immediately older phase with Anaro circle-stamped type 1 pottery, nephrite and slate, associated with three $\mathrm{C} 14$ dates between $500 \mathrm{BC} \mathrm{AD} \mathrm{1.} \mathrm{This} \mathrm{date} \mathrm{range} \mathrm{is} \mathrm{supported} \mathrm{by} \mathrm{the} \mathrm{date} \mathrm{of} 400 \mathrm{BC}$ (Wk 21809, Table 5.1) for a green Fengtian nephrite lingling-o from Savidug Dune Site on Sabtang Island, probably similar to ones that the nephrite debitage suggests were being made at Anaro. Other lingling-o dates from Thailand and Vietnam also fall between 400 BC and AD 1 (Hung et al. 2007).

Prior to this phase, with its typical sherds of Anaro circle-stamped type 1, comes an even earlier phase with the sherds of Anaro circle-stamped types $2 \mathrm{~A}$ and $2 \mathrm{~B}$, and presumably also types $3 \mathrm{~A}$ and 3B. Some of the latter (Fig. 6.7, sherds labelled A,B) have stepped decorative motifs very similar to those dated to c. $1200-800$ BC from Sunget on Batan and Savidug on Sabtang. The basal date of $c .1000 \mathrm{BC}$ from Anaro square 3 (2004) relates to this material.

Finally, a single sherd of fine cord-marked pottery was found in surface collections from Anaro, although no occupation level that belongs to this period has yet been found in the excavations. It is similar in fabric and temper to fine cord-marked sherds from Middle Neolithic eastern Taiwan, but future study is needed to confirm its source.

The above observations allow an overall ceramic chronology for Itbayat to be formulated, following on from the discussion in chapter 5:

1. Phase 1 , outer limits 2500 to 1000 BC: plain pottery of the types present at Torongan and Reranum Caves. Fine cord-marked sherds were still present at Reranum and possibly Anaro. Red slip was common.

2. Phase 2a, outer limits 1300 to $500 \mathrm{BC}$ : circle-stamped pottery appears at Anaro, initially of types 2 and 3 defined above. Baked clay figurines and spindle whorls (chapter 7) were also present at this time, according to their circle-stamped decoration. Taiwan nephrite and slate were probably present.

3. Phase 2b: outer limits $500 \mathrm{BC}$ to AD 1: Anaro circle-stamped type 1 vessels. Taiwan nephrite and slate were now being worked at Anaro.

4. Phase 3, outer limits AD 1 to 1200: Mitangeb and Anaro plain ware, with no surface decoration at all and no appendages. Corrugated rims are present, as in early Indic contact phase sites in Bali. Iron appeared, but nephrite and slate are not so far reported.

5. Phase 4, commencement AD 1200: plain wares with short rims became universal, as in the top $50 \mathrm{~cm}$ in the Anaro 3 excavated squares. Chinese imports and glass beads also belong in this phase.

\section{The Sunget pottery, Batan Island, 1200 to $800 \mathrm{BC}$}

The two Sunget sites (Top and Main Terraces), located on the ridge above Mahatao township on Batan, were excavated three times, in 2002, 2003 and 2004, as described in chapter 3. The materials recovered on each occasion were clearly part of a single assemblage, and identical to the materials recovered by the Kumamoto University team in the road cutting immediately below the Main Terrace in 1982. These two Sunget localities, as well the road cutting location, were occupied only for a short time between 1200 and $800 \mathrm{BC}$, when the present town site of Mahatao was occupied by a marine bay. This was about 1500 years before the major Iraya eruption that filled the bay and provided the large area of flat land upon which Mahatao township sits today. Since about 800 BC, the Sunget Ridge has only been used for agricultural purposes, not occupation, and this means that the whole assemblage from 1982 onwards can be ascribed to one short phase of prehistoric activity. 
The pottery discovered at Sunget in 2004 was essentially identical to that recovered in 2002-3, described in Bellwood et al. 2003 (pp. 151-3 and Figs 11-15). Within the Batanes Islands, its closest relationships in shape, but not decoration, are with the assemblage from Reranum Cave on Itbayat, particularly in its preferences for tall rims ( $80 \%$ over $3 \mathrm{~cm}$ high - see above) on restricted vessels, and for quite tall ring feet. Sunget, however, unlike Reranum, lacks sherds of cord-marked pottery.

The Sunget pottery (Figs 6.12 to 6.14), like that from Torongan and Reranum, was probably once mainly red-slipped, to judge from surviving traces on sherds. The profiles shown are virtually identical to those published by Koomoto (1983: Figs 15-17) and are dominated by globular vessels with tall everted rims, the majority being internally concave. The Japanese team also published a number of loop handles and phallic-like appendages, similar to those from the contemporary occupation at Anaro on Itbayat. There are also a few carinated body sherds, flat-topped or knobbed lids, and open bowls decorated with multiple-rowed zones of Z-shaped stamped circle motifs, paralleled but rare at Anaro and Savidug Dune Site. Koomoto (1983) reconstructed some of these open bowls as being on pedestals, and some of the globular restricted vessels were also on ring feet. The stamped circle decoration was originally filled with a white substance (Fig. 6.13), either clay or lime. One example from an incised sherd was identified by geologist Alan Watchman as white clay, presumably added deliberately by the potter.

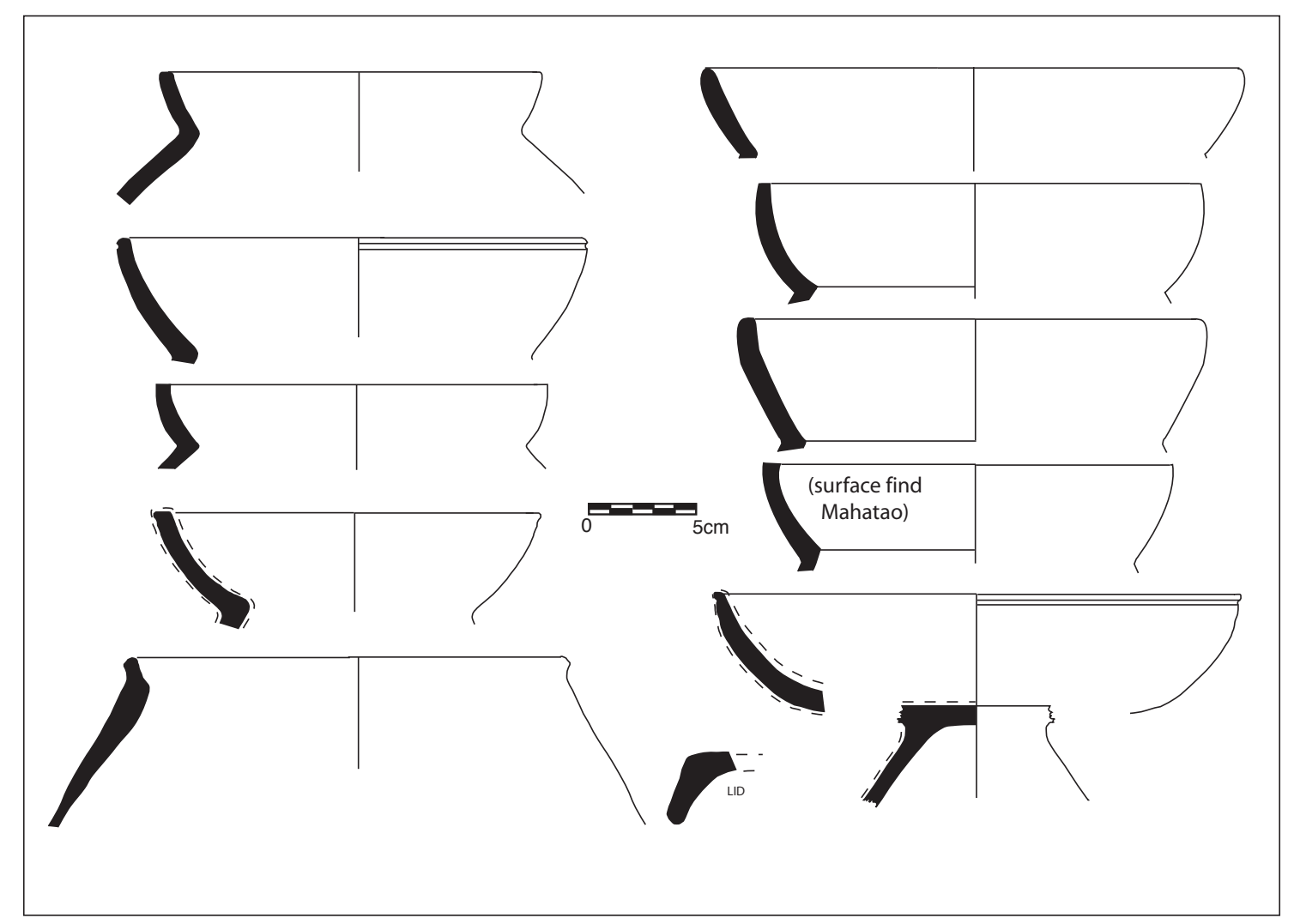

Figure 6.12. Profiles of Sunget pottery excavated between 2002 and 2004, from the Top and Main Terraces. Dotted lines indicate visible red slip, although most might have been slipped originally.

Source: Peter Bellwood.

Some further points about the Sunget pottery are worthy of note. Firstly, several vessels, both restricted and unrestricted, have a shallow groove just below the outer edge of the lip (Fig. 6.12), a feature paralleled in much of the pottery from the contemporary lower layer of Savidug. There 
are also many everted rims that are internally concave, like many of the rims from Reranum (Fig. 6.3). As noted, there is no cord marking at Sunget, and therefore the assemblage must post-date the period of cord-marking dominance in southeastern Taiwan, a dominance that was already on the wane by 2000/1500 BC according to the evidence from Chaolaiqiao (Hung 2005, 2008). The corollary of this is that Sunget does not have occupation from the initial settlement phase on Batan. Such might lie beneath the deep ash mantle that buried the original coastal Neolithic settlement in Mahatao itself, just downhill from the Sunget sites (see discussion in chapter 3), but this material was too deeply buried for us to reach by excavation.

\section{The lower occupation in Savidug Dune Site, Sabtang Island (1200 BC to AD 1)}

As noted in chapter 4, the lower cultural layer in the Savidug Dune Site can be divided into

a) an earlier phase associated with red-slipped and rare circle-stamped pottery, with Sunget and basal Anaro parallels, dated 1200 to $700 \mathrm{BC}$;

b) a later phase, dated $c .700 \mathrm{BC}$ to the early centuries $\mathrm{AD}$, associated with jar burial, Taiwan nephrite, and possibly copper working.

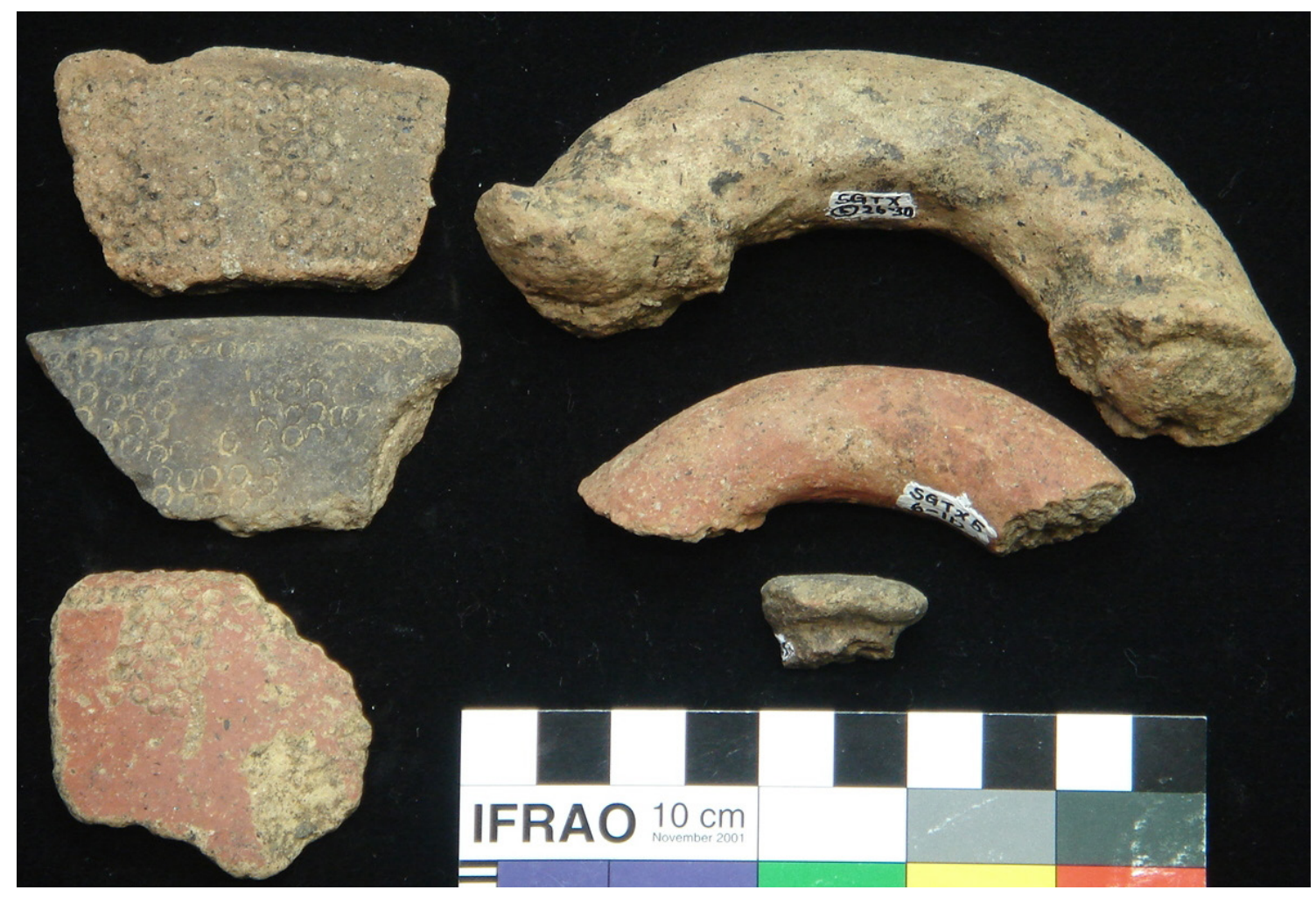

Figure 6.13. Left: circle-stamped sherds from the Sunget excavations. The top two are open bowl rims, the lower redslipped piece appears to abut a carination. The middle sherd still has white infill. Right: two loop handles (one redslipped) and a lid knob from Sunget.

Source: Peter Bellwood.

Savidug Dune Site was uninhabited through most of the first millennium AD, but occupation started again in late prehistory, with a different local pottery style associated with Chinese ceramic imports and intriguing evidence for a heavy impact on reef resources (chapter 12). This later pottery assemblage will be described separately towards the end of this chapter. 
The basic distribution of sherdage throughout most of the Savidug Dune Site excavations is shown in Table 6.6. The 2006 test trench had an upper cultural layer (layer 2) with very sparse pottery, then a rich lower cultural layer (layer 4) beneath the sterile sand layer 3. This lower assemblage contained many very large sherds and appeared to represent a relatively short period of cultural activity that was quickly buried under encroaching sand. The sherds excavated in 2006 from this lower layer are shown as a group in Fig. 6.15, and were stratified just above the radiocarbon date of $c .1000 \mathrm{BC}$ (Wk 19711, Table 5.1). The vessel forms are mostly red-slipped, and the Savidug sand dune appears to have been a favourable environment for preservation in this regard. Everted rims tend to be tall, and some have grooves externally just below the lip (Fig. 6.15 A, B, D, E, K), similar to the Sunget assemblage. There is also a small carinated red-slipped vessel (Fig. 6.15 L), and a red-slipped everted rim with an appliqué band around the external neck (Fig. $6.15 \mathrm{I}$ ), impressed repeatedly with what appears to have been a small round stick. We will meet these forms again in Sandy De Leon's analysis of Savidug rims (below). One sherd, Fig. 6.15 E, has horizontal parallel lines on its upper surface suggesting use of a slow wheel in manufacture.

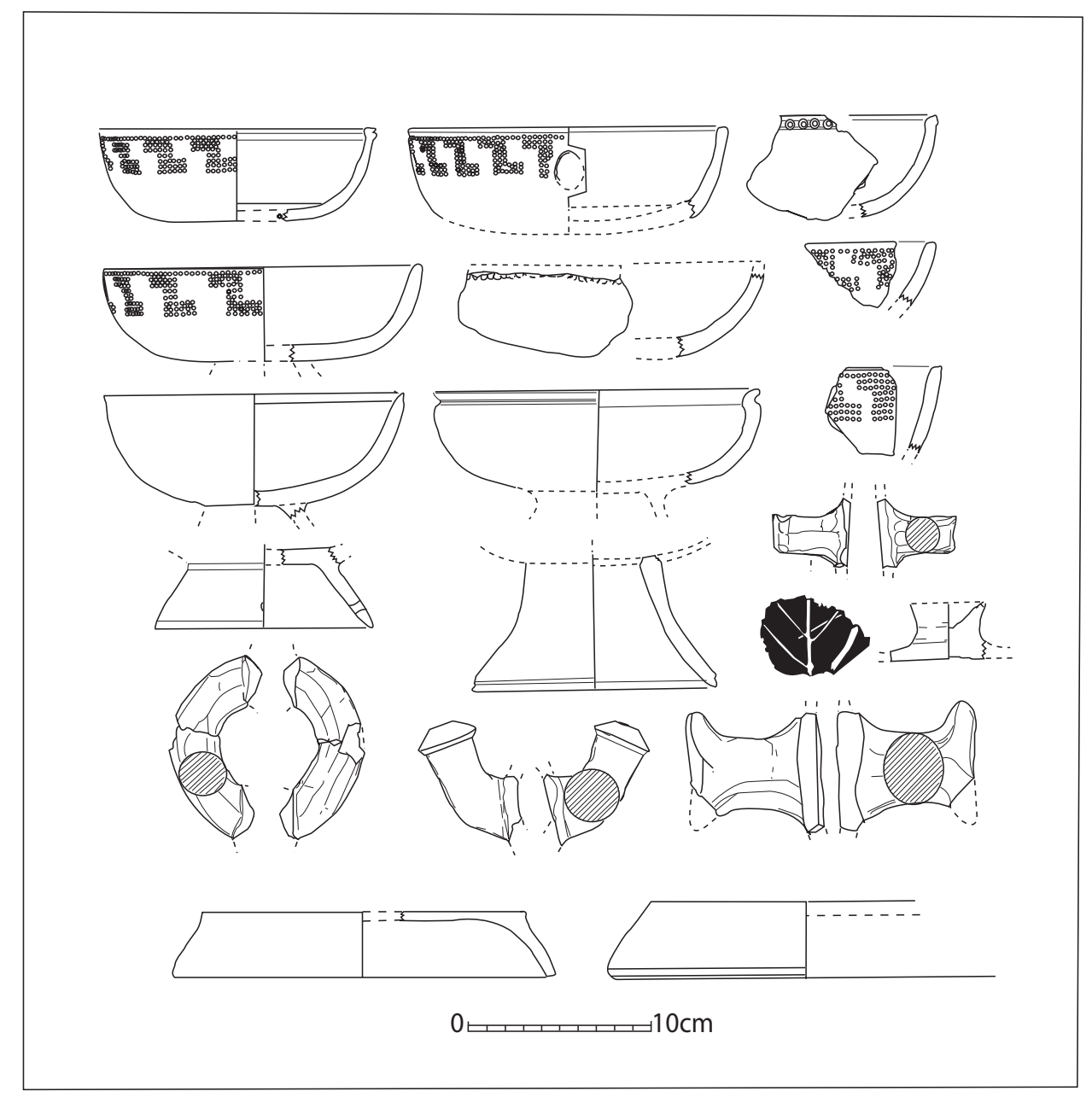

Figure 6.14. Open bowls with stamped circle decoration, handles, knobs and lids from Sunget.

Source: From Koomoto 1983, reproduced with permission.

Overall, the Savidug rims are similar in shape and size to those from Sunget, except in the rarity of circle-stamping and the absence of the everted and internally concave rim which dominates the Sunget assemblage. The total of four excavated circle-stamped sherds from Savidug are shown in Fig. 6.16. Sherds C (QR7-9 170-180 cm) and B $(2006,180 \mathrm{~cm})$ are both from the basal layer in 
the site and carry the Z-shaped Sunget circle-stamped design, but since the circles are of different sizes they probably come from separate vessels. The same design occurs on the rim fragment $\mathrm{D}$ with a broken handle attachment from QR/7-9 170-180 cm, and this has the same profile as rim B. Rim A, a surface find, looks like an Anaro circle-stamped type 1 rim, except that the pattern is a zigzag rather than a lattice. Rim and handle combination $\mathrm{E}$ has double rows of stamped circles that might also be of the Sunget design. Overall, these few stamped sherds indicate occupation at Savidug throughout the general life span of circle stamping in Batanes, from perhaps $1200 \mathrm{BC}$ to $\mathrm{AD}$ 1. It is quite possible that some of the sherds were imported from Batan Island, since some appear similar to Sunget pottery fabrics in having quite dense small black inclusions.

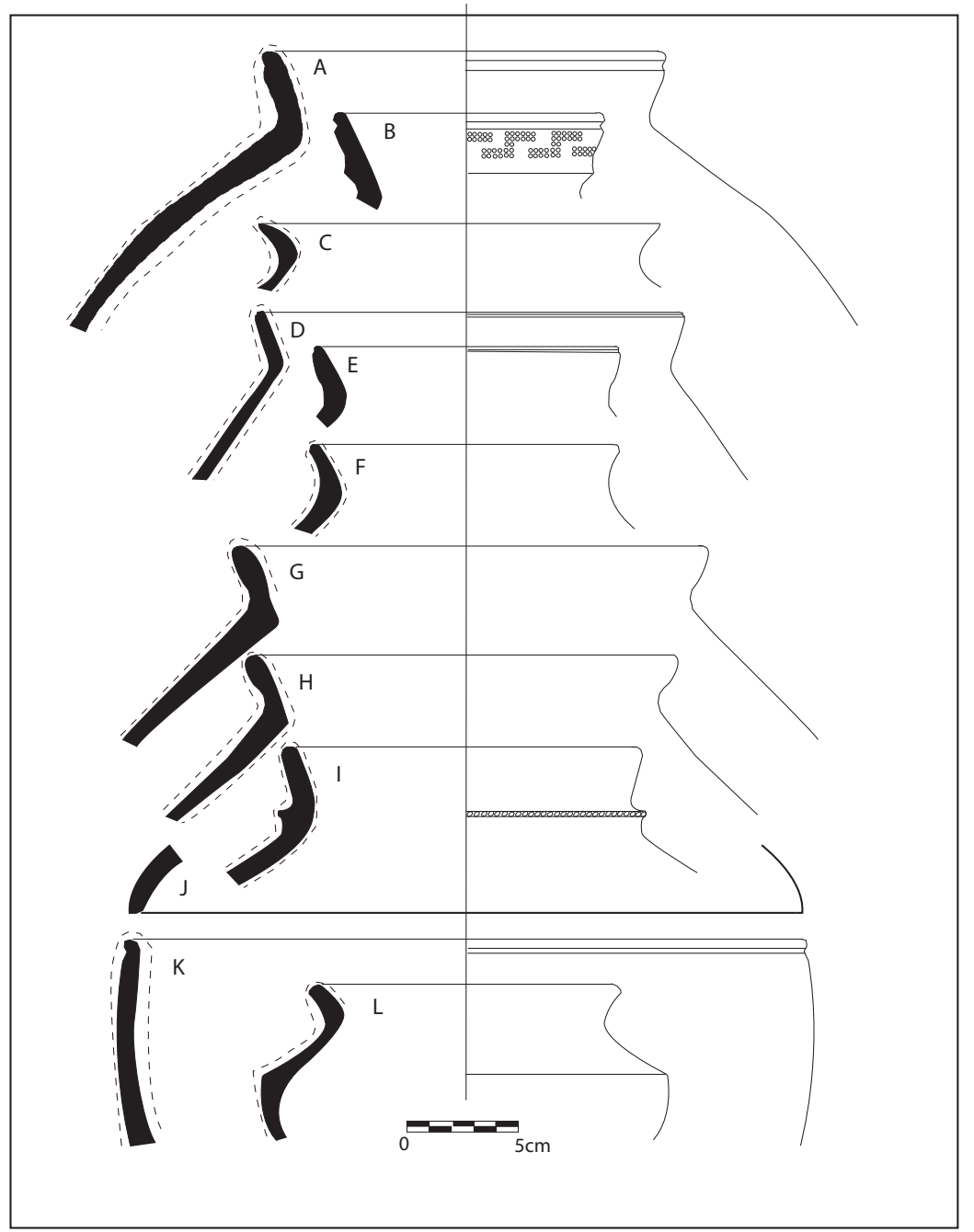

Figure 6.15. Vessel group excavated from layer 4 in the Savidug Dune Site test trench in 2006, stratified above a C14 date of c. 1000 BC. Item B is also shown as Fig. 6.16 B.

Source: Peter Bellwood.

From the 2007 excavation, Trench K-N/27-29 had very limited remains from layer 4 (the lower cultural layer), which had here virtually disappeared. Trench QR/7-9 was much more prolific, and the pottery from here is described in more detail by Sandy De Leon below. Table 6.6 indicates that the pottery in layers 4 and 5 in QR/7-9 occurred with two sharp peaks in sherd numbers at about 120 and $170 \mathrm{~cm}$. Average sherd weights at Savidug are quite high compared to those at Anaro, suggesting that protective burial was quite rapid in the soft sand dune environment. In 
QR/7-9, the percentages of everted rims over $3 \mathrm{~cm}$ tall increase fairly regularly downwards from top to bottom of the lower cultural layer, placing this early Savidug assemblage between Sunget and Mitangeb in time from a typological perspective.

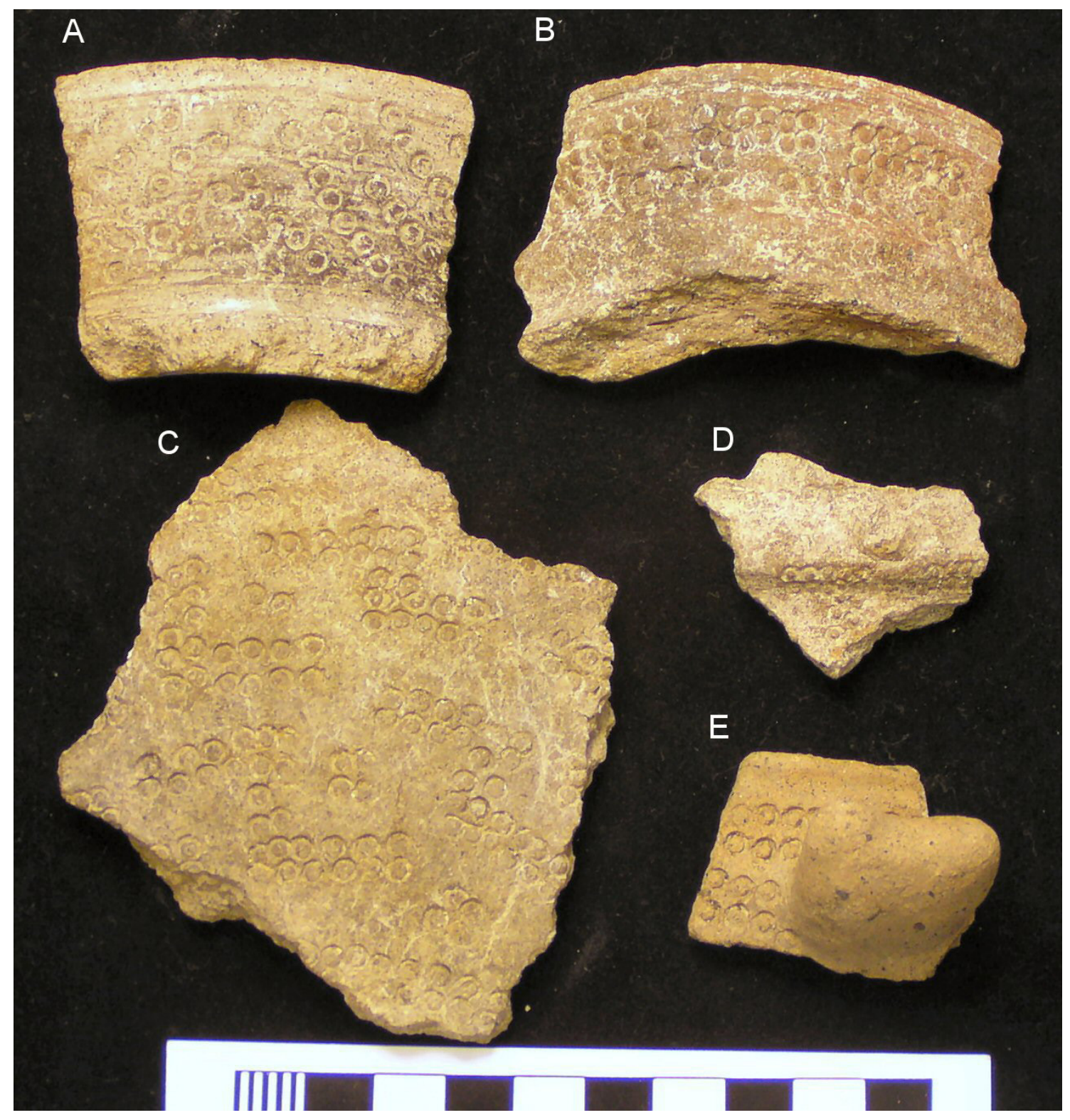

Figure 6.16. Circle-stamped sherds from the Savidug Dune Site. A: rim from road cutting with Anaro circle-stamped type 1 shape and pattern. B. Rim with Sunget-style decoration from the 2006 trench at $180 \mathrm{~cm}$ (basal layer 4). C: Body sherd with identical pattern from QR/7-9 170-180 cm. D: rim fragment with broken handle attachment, very similar to rim B, from QR/7-9 130-140 cm. E: surface find of an apparent bowl rim with a lug and decoration of double rows of circles.

Source: Peter Bellwood. 


\section{Savidug Dune Site and Anaro: A comparison of pottery attributes (by Alexandra De Leon)}

In 2008, a University of the Philippines thesis on the pottery excavated in 2007 from Savidug Dune Site was completed by Alexandra De Leon, who compared 335 diagnostic sherds from layers 4 and 5 (lower cultural layer) in Savidug trench QR/7-9 with 250 sherds from the excavated square Anaro $3 \mathrm{~B}$ on Itbayat. The objective of this research was to identify similarity or variation within and between the two assemblages in order to address issues of interaction between the two islands. The focus of the comparison was on rim sherds. First to be described is the Savidug sample.

\section{Savidug}

In Savidug trench QR/7-9, pottery occurred throughout the $130 \mathrm{~cm}$ thick lower cultural layer, dated to the first millennium BC, between 90 and $220 \mathrm{~cm}$ below the present ground surface (Table 6.6). Rim sherds from this sample were first of all refitted where possible, leaving rims belonging to 256 separate vessels for analysis. These rims can be categorised as belonging to bowls (Fig. 6.17, left side), hole-mouthed vessels (Fig. 6.18, left side), and jars with everted rims (Fig. 6.19, left side). Within the QR/7-9 lower cultural layer sample there are 30 bowl rims (12\%), 10 hole-mouthed rims (4\%) and 216 everted jar rims (84\%).

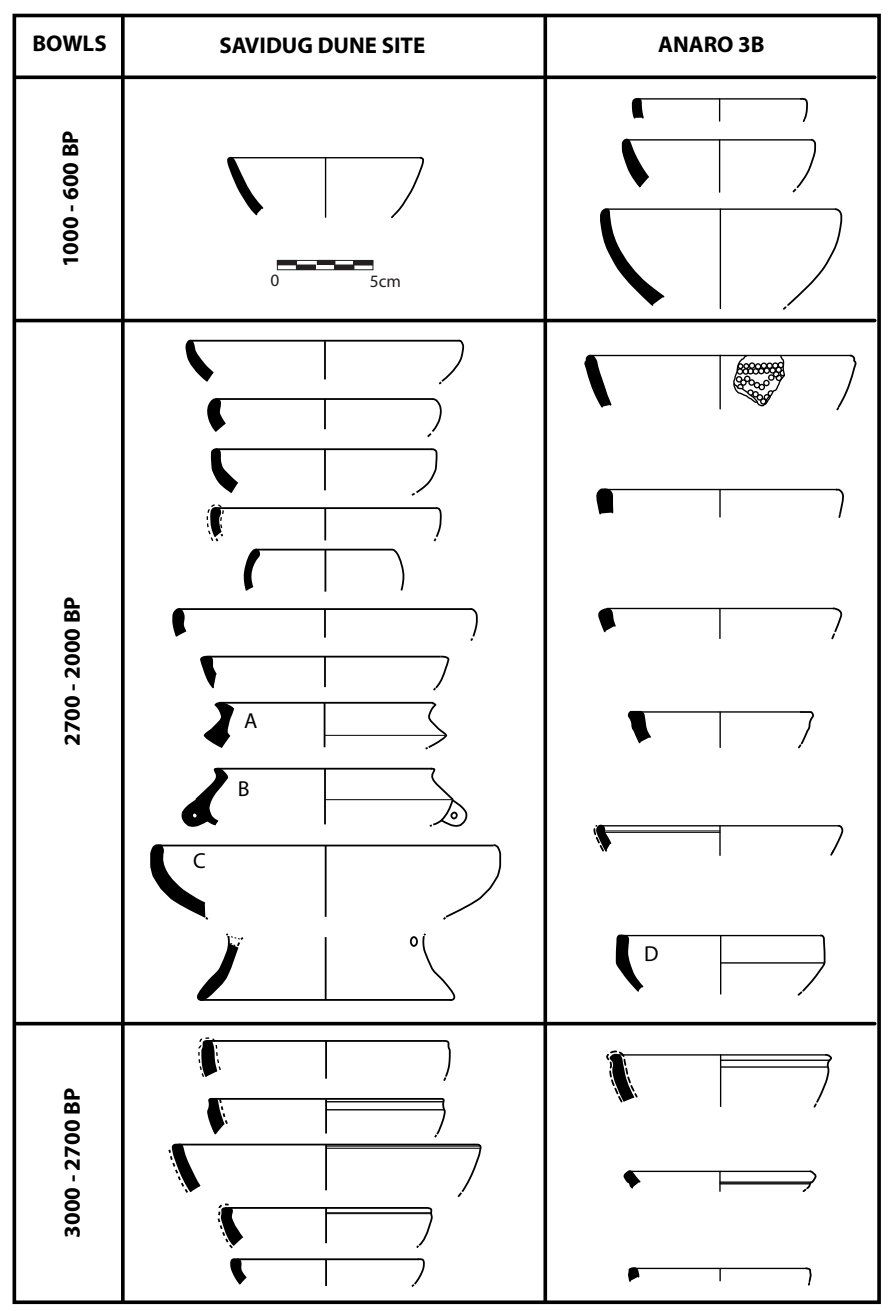

Figure 6.17. Bowl sections compared from Savidug QR/7-9 and Anaro 3B. 


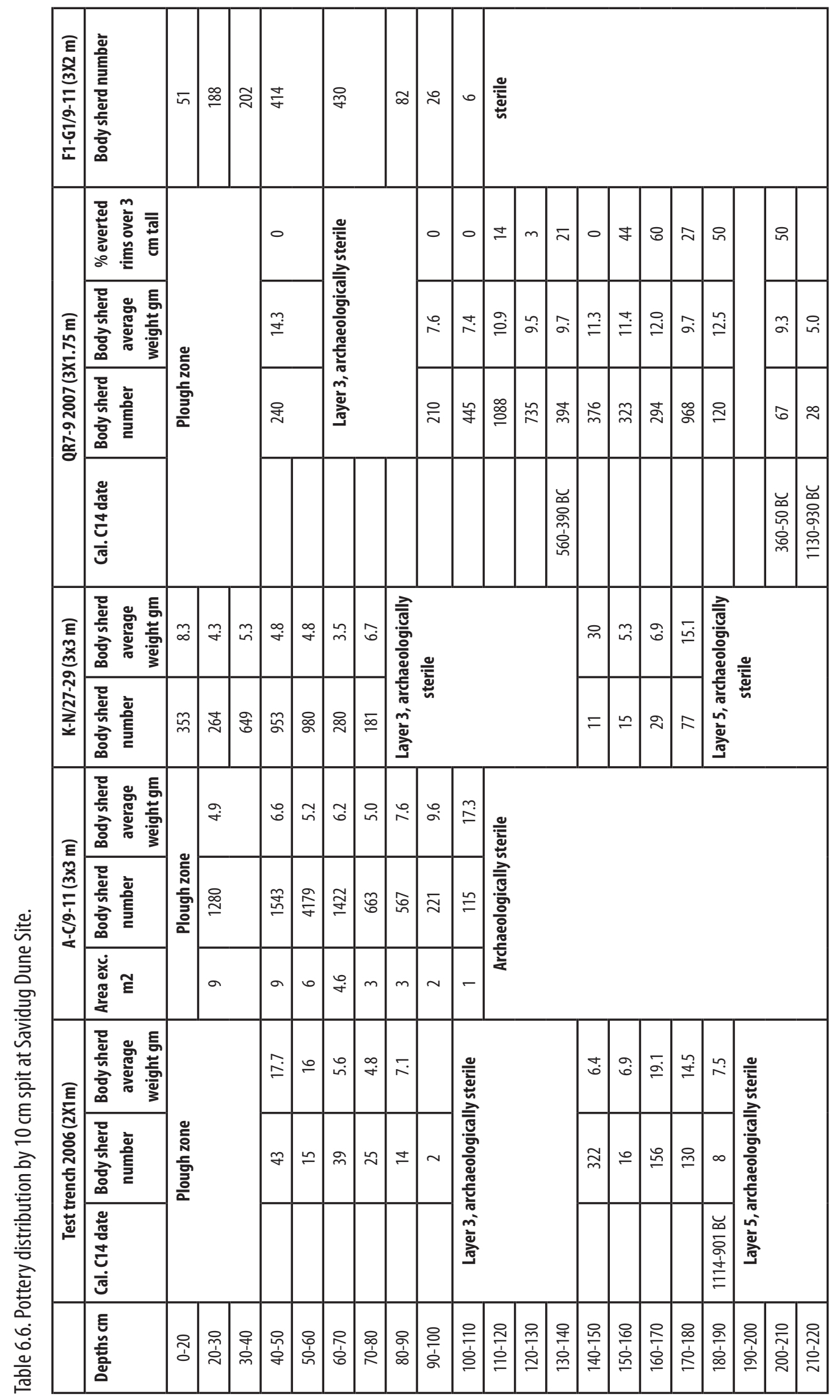




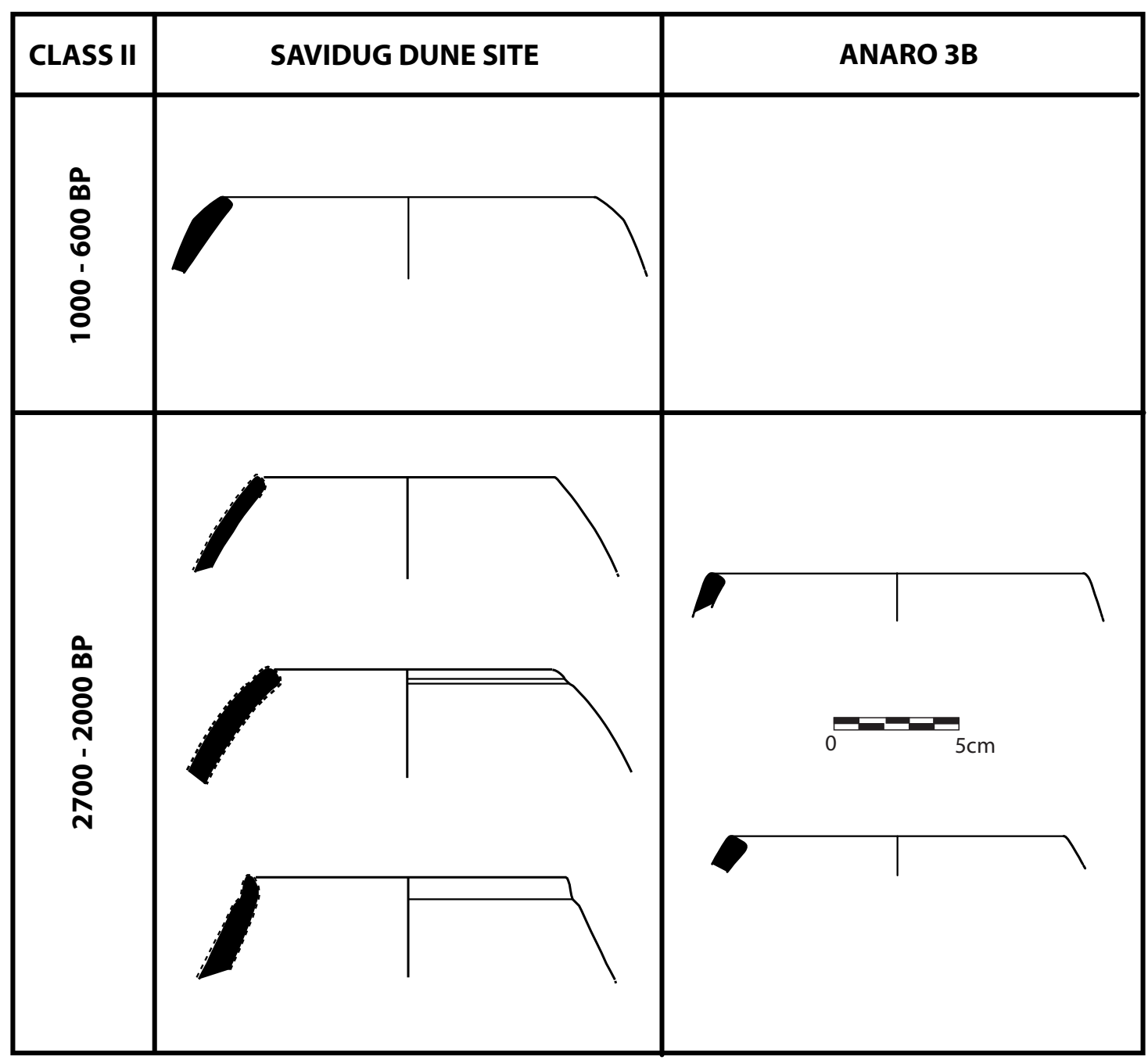

Figure 6.18. Hole-mouthed rim section compared from Savidug QR/7-9 and Anaro 3B.

Source: Alexandra De Leon.

Savidug bowl rims can be unrestricted (open), or restricted and carinated. Some bowls were probably on pedestals. The rim profiles of the open bowls are mostly parallel-sided and rounded at the lip, but below $140 \mathrm{~cm}$ they sometimes have outer grooves below the lips, like Sunget pottery. Open bowls vary in mouth diameter and can be grouped into small $(11-12 \mathrm{~cm})$ and large $(17-26 \mathrm{~cm})$ classes, the latter being in the majority. Red-slipping was used more frequently to finish vessels in the earlier spits. It continues in the upper spits, but polished and smoothed bowls here become more common.

Restricted and carinated bowls comprise only 3 specimens, found between 90 and $150 \mathrm{~cm}$. Two are similar, with short, pointed and out-curving rims (6.17 A, B), but belonged to different vessels. One has a lug attached just below the carination $(6.17 \mathrm{~B})$. Both are $18 \mathrm{~cm}$ in mouth diameter. The bowl reconstructed as having a pedestal in Fig. $6.17 \mathrm{C}$ is larger, at $27-28 \mathrm{~cm}$ diameter.

The second, hole-mouthed, form in the QR/7-9 pottery assemblage has an unthickened inverted rim which forms a round hole-mouth ( $\mathrm{N}=10$, or $4 \%$ of the assemblage) (Fig. 6.18). They occur only in the upper and middle portions of the QR/7-9 lower cultural layer, between 110 and 170 
$\mathrm{cm}$. Some of the earlier examples have an external groove below the lip, like the bowls (above), and again paralleled in the Sunget assemblage (although this kind of hole-mouthed vessel has not been recognised at Sunget).

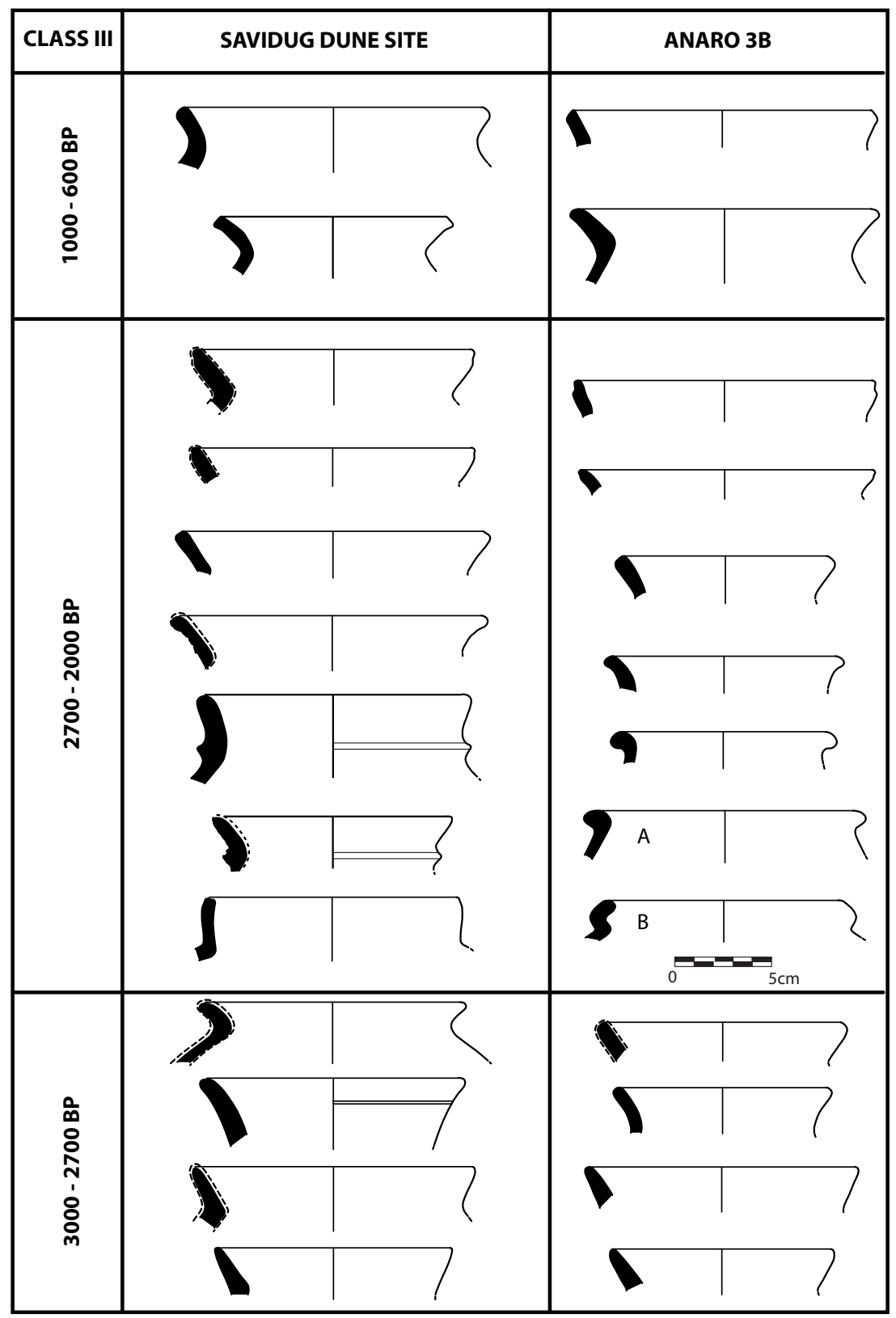

Figure 6.19. Jar rims compared from Savidug QR/7-9 and Anaro 3B.

Source: Alexandra De Leon.

In some cases, these hole-mouthed rims could have belonged to large carinated bowls, but such forms can no longer be reconstructed so they are identified as a separate class for the purposes of this analysis. Mouth diameters range from 8 to $17 \mathrm{~cm}$, with the earlier ones tending to be larger than the later. Hole-mouthed vessels have a surface finish that is either red-slipped (60\%) or polished black. Red-slipping is more common in the lower levels.

Everted jar rims (Fig. 6.19) are the most common form at Savidug, representing at least 216 vessels, or $84 \%$ of all rims from the lower cultural layer. They occur throughout from $90-220 \mathrm{~cm}$, 
but are especially dense at the 110-130 cm level. Most rim profiles are unthickened and parallel, but a few also converge towards the lip. As with the other vessel forms, red-slipping is more common in the lower levels. The mouth diameters of these simple everted jar rims range from 9-25 cm, with no clearly differentiated categories, perhaps due to wide variation in function. External grooves below the lips also occur only in the lower half of the profile, below $140 \mathrm{~cm}$.

One important variety of jar rim that is common at Savidug has an applied band around the external neck, in many cases impressed with what appears to have been a small round stick (as discussed above for the 2006 assemblage for the site) (Fig. 6.20). In QR/7-9 they occur in the upper part of the lower cultural layer above $150 \mathrm{~cm}$, except for one from the $180-200 \mathrm{~cm}$ level. Many are red-slipped. It is interesting that the single example found in 2006 (Fig. 6.15 I) was also from the top of the lower cultural layer as excavated in that season, suggesting that this form was most favoured after c.700 BC.

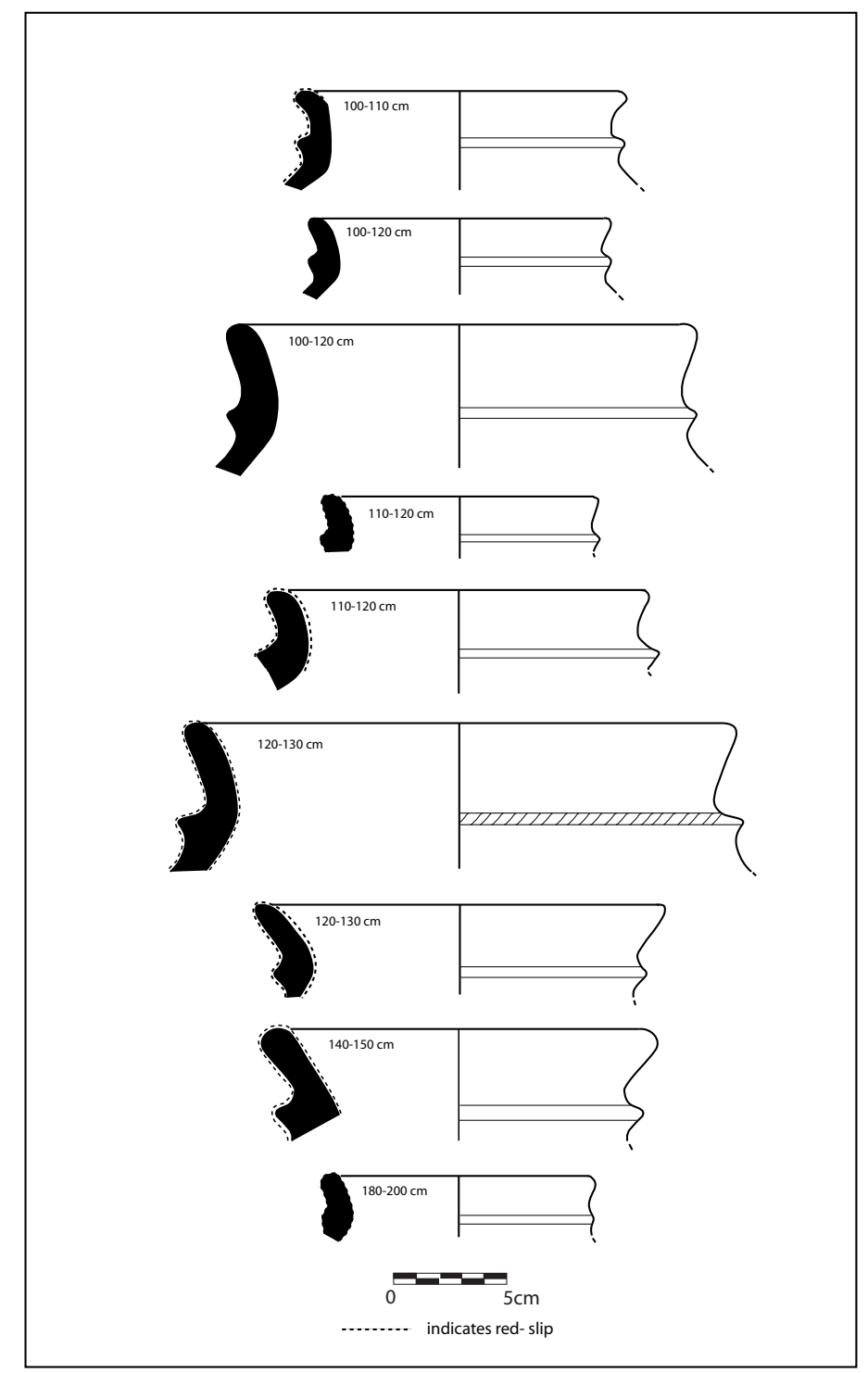

Figure 6.20. Jar rims with external applied bands from Savidug QR/7-9.

Source: Alexandra De Leon. 
Rim heights for the total of 200 everted jar rims from QR/7-9 have been measured, and provide extra detail to the discussion presented above (Table 6.3). Using the percentages of rim heights over $3 \mathrm{~cm}$ per $10 \mathrm{~cm}$ spit, a statistic that is more informative than average rim height, we see the following trend with depth:

$\begin{array}{ll}90-100 \mathrm{~cm} & 14 \%(\mathrm{~N}=7) \\ 100-110 \mathrm{~cm} & 20 \%(\mathrm{~N}=20) \\ 110-120 \mathrm{~cm} & 31 \%(\mathrm{~N}=51) \\ 120-130 \mathrm{~cm} & 30 \%(\mathrm{~N}=30) \\ 130-140 \mathrm{~cm} & 48 \%(\mathrm{~N}=21) \\ 140-150 \mathrm{~cm} & 47 \%(\mathrm{~N}=17) \\ 150-160 \mathrm{~cm} & 59 \%(\mathrm{~N}=22) \\ 160-220 \mathrm{~cm} & 62 \%(\mathrm{~N}=21)\end{array}$

The lowest $60 \mathrm{~cm}$ has been treated as one spit to maintain a rough parity of sample size, but the general trend is still very obvious, and is paralleled almost exactly at Anaro (Tables 6.1 and 6.2).

There remains one very important sherd from QR/7-9 110-120, not analysed in Manila since it was sent to Canberra after the excavation in 2007. In is shown in Fig. 6.21, and is an inflected bulbous rim of what might have been a water jar, red-slipped on the exterior, slightly concave on the interior, and of a smooth pale brown fabric with a very fine temper. The red-slipping and fabric relate this vessel to the red-slipped carinated jar shown as Fig. $6.15 \mathrm{~L}$, and several similar carinated sherds were found in the 2006 excavation, all with the pale brown fabric that appears to be foreign to the rest of the Savidug assemblage. The rim does not match any specific carinated sherd, but it is not difficult to imagine that it was once attached to a carinated pot like Fig. 6.15 $\mathrm{L}$, at the top of a vertical spout. Should this seem far-fetched, two vessels of such a shape, from the site of Gunung Piring on Lombok Island, central Indonesia (Gunadi et al. 1978; Bellwood 2007: Plate 60), are likely to be contemporary with Savidug QR/7-9 and late first millennium $\mathrm{BC}$ in date. Although Gunung Piring yielded extended burials and Savidug has jar burials, the question arises whether this rather striking kind of red-slipped pouring vessel was widely traded in the islands of Southeast Asia. To determine this, we need analysis of pottery fabrics.

\section{Anaro 3B}

250 diagnostic sherds were studied from Anaro square 3B, excavated from $0-120 \mathrm{~cm}$ below the present surface. The sample includes 202 rims, 32 decorated body sherds, 8 carinated sherds, 7 foot rings and one ear/lug, belonging to at least 187 vessels. The basic vessel forms are the same as at Savidug - bowls, hole-mouthed vessels, and jars. Samples are shown down the right hand sides of Figs 6.17 - 6.19 for comparison with Savidug.

As mentioned in chapter 2 , it was discovered after this analysis had commenced that the radiocarbon dates for Anaro 3B did not correlate with those from Anaro 3A, perhaps due to erosional and disturbance factors in the case of 3B. The Anaro 3B assemblage is therefore studied here mainly for comparative purposes with Savidug, rather than to establish chronological markers.

Bowl forms (Fig. 6.17) with direct rims make-up 20\% of the Anaro 3B assemblage, as opposed to $12 \%$ at Savidug. They can, as at Savidug, be categorized as open bowls and (slightly) restricted and carinated bowls, and some were possibly on pedestals. They tend to have parallel-sided rims with mostly flat lips, although there is some variation. External rim grooves and circle-stamped 
designs tend to be concentrated in the lower spits, as already noted. The three carinated bowls from Anaro 3B, found between 60 and $70 \mathrm{~cm}$, have flat lipped parallel-sided rims with slightly incurving tendencies (Fig. 6.17 D). All are polished and plain.

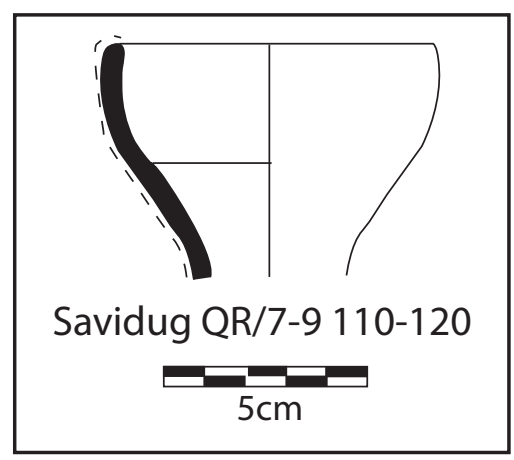

Figure 6.21. Bulbous spout of a vessel for holding liquids from Savidug Dune Site QR/7-9.

Source: Peter Bellwood.

Anaro 3B has only two potential examples of the hole-mouthed vessel form (Fig. 6.18), found in the middle spits between 65 and $80 \mathrm{~cm}$. The everted jar rims (Fig. 6.19) from Anaro 3B belong to at least 139 vessels (either cooking pots or storage jars) that represent $71 \%$ of the analysed assemblage. Rims of this type are mostly out-curving, parallel-sided in profile and round lipped. Below $60 \mathrm{~cm}$, however, some everted rims exhibit unique profiles, such as the squat and rounded and S-profiled rims shown as Fig. 6.19 A and B. Externally grooved rims are again restricted to the lower spits. The heights of the rims range from 1.0 to $5.0 \mathrm{~cm}$, with an average of 1.96 . However, short rims (under $1 \mathrm{~cm}$ ) and tall rims (over $4-5 \mathrm{~cm}$ ) occur only below $60 \mathrm{~cm}$ (see also Table 6.1).

\section{A comparison of trends through time at Savidug and Anaro}

Were the inhabitants of Sabtang and Itbayat islands in contact during prehistory? Since the islands are intervisible this seems very likely. To assess the likelihood, the pottery assemblages from the two sites have been compared in terms of rim form and surface decoration. Results of a petrographic analysis of sherd thin sections from both sites are also presented below.

Generally, vessel shapes at both Savidug and Anaro are similar. Jars with everted rims dominate both assemblages. Ancillary features such as lugs, carinations and foot rings are present in both sites. Rim attributes are similar, but by no means identical.

Amongst the bowls, the fairly standard open form occurred throughout both sites, largely characterized by flat lipped, parallel-sided rims that are either straight or incurving. As noted, external grooves just below the lip occur in both Savidug Dune Site (in several levels below the jar burials) and in the lower levels of Anaro 3B, and this form also exists at Sunget on Batan island. However, the carinated bowls of Savidug and Anaro are rather different, with slightly more complex rim forms at Savidug (Fig. 6.17). Moreover, the pedestals/foot rings from Savidug are rather wide and tall, having foot diameters of 15 to $25 \mathrm{~cm}$ and heights of 4.5 to $5.5 \mathrm{~cm}$. The foot rings from Anaro are smaller and shorter, 8 or $9 \mathrm{~cm}$ in diameter and 1 to $2.5 \mathrm{~cm}$ in height. It should be mentioned that indeterminate fragments of foot rings occur in the lower levels at both Savidug and Anaro, suggesting that this form appeared early in both sites. 
Hole-mouthed vessel rims make up the smallest portion of the pottery assemblages at both Savidug and Anaro. They appear at the same time in both sites, perhaps between $700 \mathrm{BC}$ and $\mathrm{AD} 1$, in the upper to middle spits of the Savidug QR/7-9 lower cultural layer and the middle to lower levels of Anaro 3B.

The earliest everted jar rims at Savidug and Anaro are mostly parallel-sided and round-lipped, with either straight or incurving courses. They have diameters that range from $10-21 \mathrm{~cm}$ and rim heights from 1 to $4 \mathrm{~cm}$. Again, external grooves are typical in the lower spits in both assemblages. Squat and S-profiled rims appeared uniquely at Anaro, but rims with external appliqué bands around their necks occur only at Savidug.

As discussed above, both sites have stamped-circle decorative motifs, although much more commonly at Anaro. Incision occurs but is rare in both sites. Neither has cord-marking, apart from a single undated surface find at Anaro.

\section{Fabric analysis}

Thin section analysis was carried out on 15 sherds from Savidug and Anaro in order to define the nature of the mineral inclusions in the pottery from both sites, and to identify any movement of pottery between islands. Samples were analysed in Manila and only included plain sherds, since the decorated sherds were in Canberra at the time of the analysis. Petrographic analysis was carried out by Dr Balangue Tarriela and Mr Adrian Fernandez at the University of the Philippines National Institute of Geological Science. This showed that the inclusions in the sherds from both sites are mainly grains of plagioclase. Other minerals associated with volcanic or igneous rocks, such as amphibole, biotite, pyroxene and quartz, occur at varying frequencies. Organics and mineral oxides also occur. The Savidug pottery on average has more frequent plagioclase grains and a large proportion are coarse in size. At Anaro, the minerals are weathered (detrital) and the plagioclase and other grains are finer in size. Almost all samples show poorly sorted grains. No calcite grains occurred in the sherd samples in either site, which may be significant considering that Anaro is located in a karstic environment and Savidug is located in a coastal area with both living and raised coral. In terms of soil chart colours, the overall matrices of Savidug pottery in cross polar light are gley, while those of the Anaro pottery are reddish orange.

In sum, the petrographic analysis indicates that both the Savidug and Anaro pottery assemblages were composed of similar volcanic minerals. However, despite the similarities in mineral composition, the characters of the minerals present in each site vary. This indicates that the raw materials came from different geological sources. The locations of these sources are not a subject of this study, but the large plagioclase grains which occur in the thin sections from Savidug are consistent with the character of the Sabtang island volcanic rocks, while the weathered minerals, oxides and the mostly reddish nature of the Anaro thin sections also coincide with the nature of Itbayat volcanic geology. This suggests that pottery was produced locally in both islands, and not traded between islands in large quantities. A similar conclusion concerning pottery fabrics was also reached by William Dickinson (2006), after his petrographic examinations of sand tempers in sherds from Taiwan, Batanes and Luzon that were under analysis by Mary Clare Swete Kelly for her ANU PhD thesis (Swete Kelly 2008). Needless to say, further sourcing studies should be undertaken to determine specific sources of raw materials to fully understand the nature of pottery production in prehistory.

At this point, the continuing similarities through time in rim forms and decoration can best be explained by cultural interaction rather than pottery trade between the occupants of the two sites, 
and the Batanes Islands in general. However, the possibility of some inter-island trade in unusual and specialised vessel forms has been raised above, and further research on this topic is clearly needed.

\section{Post-Sunget assemblages on Batan, prior to the Iraya eruption (200 BC to AD 500)}

A number of sites belonging to this phase on Batan were investigated in 2002 and 2003, especially at Naidi, Mahatao (through augering), Pamayan and Tayid (Fig. 3.1). These so-called "Naidi Phase" pottery assemblages on Batan (after Bellwood et al. 2003) are heavily red-slipped but have no other form of decoration such as stamping or incision (Fig. 6.22), and in particular no trace of the Anaro circle-stamped type 1 pottery style that was clearly so important in connection with nephrite working at Anaro between $500 \mathrm{BC}$ and $\mathrm{AD} 1$. Neither do any of these later Batan sites have any nephrite. For this reason, the radiocarbon dates for the Batan sites of this phase (Naidi, Mahatao, Payaman and Tayid in Table 5.1 and Fig. 5.1) are taken more or less at face value and presumed to indicate a time span between the end of the first millennium $\mathrm{BC}$ and the mid first millennium $\mathrm{AD}$, or Phase 3 in the Batanes sequence presented in chapter 5. All the sites predate the Iraya eruption, which provides a terminus ante quem of about 1500 years ago (chapter 3 ).

The closest parallels to these Naidi Phase assemblages discussed so far lie in the lower cultural layer at Savidug Dune Site and at Anaro, but the absence of stamped circles clearly places the Naidi pottery later than the Phase 2 material from these two sites. A range of Naidi rim forms is illustrated in Fig. 6.22. The same vessel forms continue as previously - bowls with direct rims and jars with everted rims - although the hole-mouthed forms are absent. External grooves just below lips continue on many everted rims, and carinated vessels occur that are similar to those from Savidug. The Payaman rims in Fig. 6.22 are well dated to the early first millennium AD. But some of the Naidi rims could be a little older. Mahurohuron and Disvayangan are close to Mahatao, with surface finds also illustrated in Fig. 6.22.

Vessel rims within the Naidi phase assemblages are generally shorter vertically than at Sunget. Of the 26 vessels shown in Fig. 6.22 that have everted rims, only 6 (23\%, mostly at the top of the figure) are greater than $3 \mathrm{~cm}$ in external height. Lips are quite often rolled or thickened externally, as shown in several examples in Fig. 6.22. This type of squat and rolled rim shape also occurs in contemporary assemblages from Savidug and Anaro, as noted in Alexandra De Leon's analysis above. Some of these rim forms are also closely paralleled in the Cagayan Valley on Luzon, for instance with the Neolithic assemblage from Irigayen (Ogawa 2002). Payaman has a number of small perforated pottery lugs that clearly belong to a separate and presumably later tradition than the large handles from Sunget.

So far, pottery of the Naidi Phase seems to be very widespread, occurring certainly beneath the major AD 500 ash fall in sites all over central Batan, both coastal and inland, such as Disvayangan (unstratified), Mahatao Town (in a septic tank pit), Buyabuy (surface finds), Mahurohuron, Mahatao Patio, Payaman, Chatavayan, Tayid, San Vicente Holiday Camp, and possibly in three other sites (K1, K6 and K41 on Fig. 3.1) recorded by Koomoto (1983). This suggests that a large population was already in occupation on Batan by this phase.

\section{Recent pottery}

Pottery from the past 1500 years can be found liberally scattered all over the Batanes landscape. No detailed study has been made of this material, although some recent rims are illustrated in Fig. 6.23 for Batan. The practice of applying red slip to pottery vessels declined after AD 500, but it never disappeared entirely and in 2003 this surface finish was still being applied using a hematiterich clay by one of the last individuals producing pottery at Itbud on Batan. Red-slipped vessels 
were also common at $c$.AD 1500 or younger at Pamayan on Sabtang. Basically, the recent pottery continued existing trends in rim length reduction, decreasing red slip and thicker vessel walls, but there was a basic continuity in vessel shapes from early to late throughout the Batanes sequence. As stated already, there is no point in the Batanes sequence where a whole new replacement pottery style can be identified as an introduction from outside.

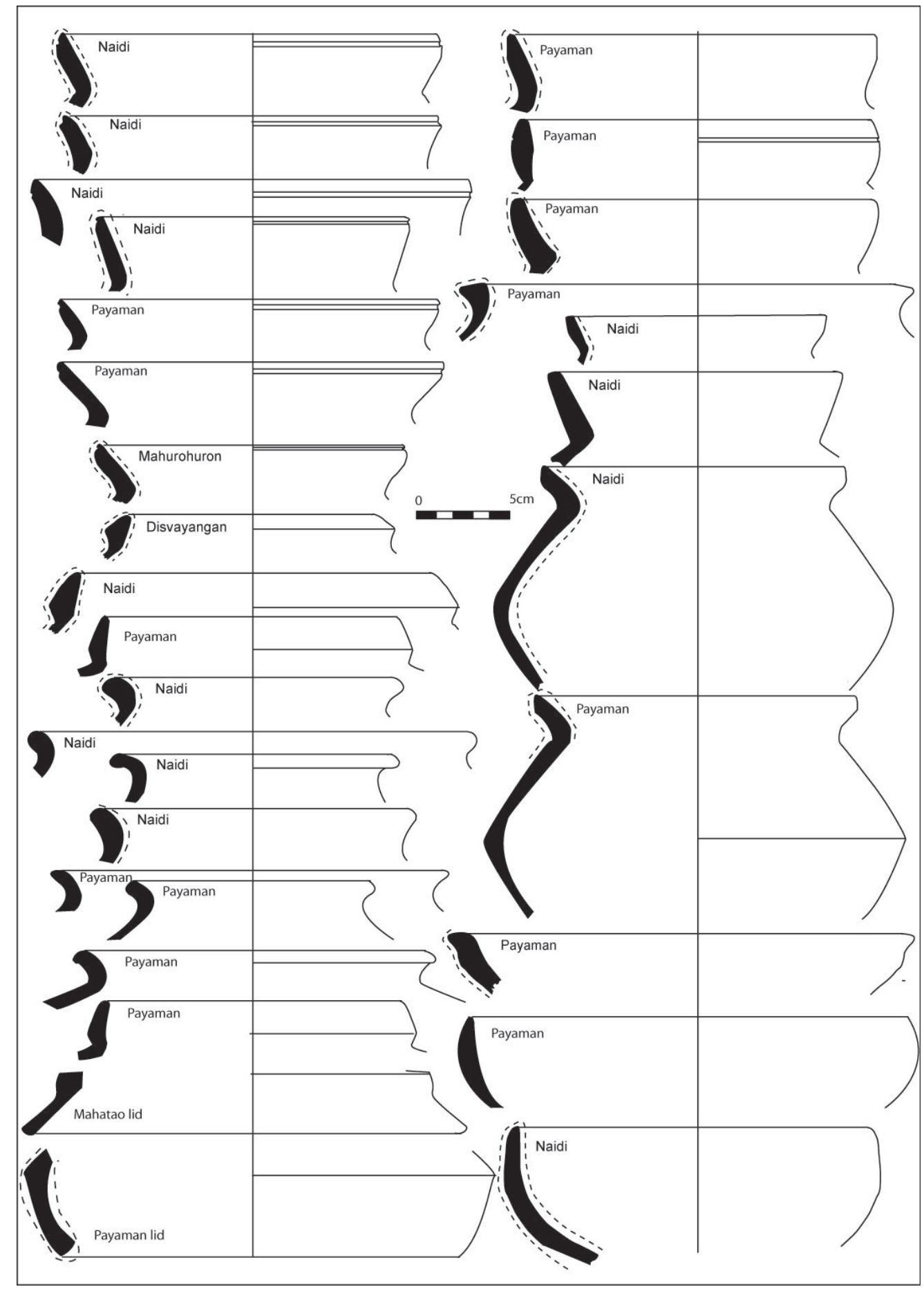

Figure 6.22. Naidi phase pottery from Batan sites: Naidi (dates uncertain), Payaman (AD 1 to 600), Mahurohuron, Disvayangan and Mahatao (surface finds).

Source: Peter Bellwood. 


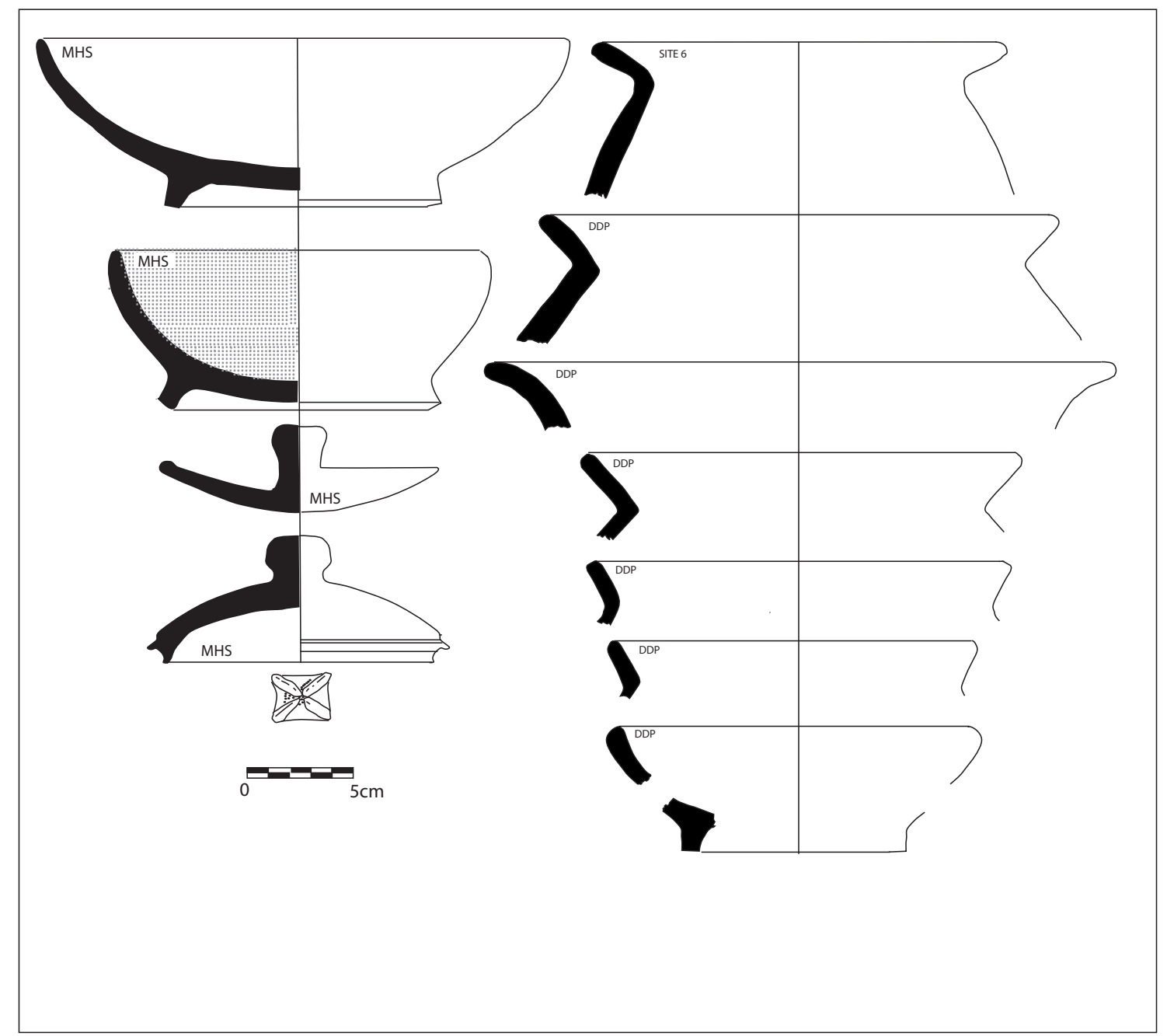

Figure 6.23. Two complete footed bowls and two lids of presumed ethnographic date kept in Mahatao High School (MHS), together with excavated late phase pottery from the Mavuyok a Ahchip (MAA) and Diosdipun (DDP) rock shelters. The bowl shown second down on the left is internally red-slipped.

Source: Peter Bellwood. 